\title{
The Association between the Perception of Aging and Functional Independence in the Elderly Patients with Type II Diabetes Mellitus
}

\author{
Farideh Bastani ${ }^{1}$, Parvaneh Beigi Boroujeni ${ }^{2}$
}

\begin{abstract}
Background \& Aims: Diabetes is a progressive, chronic disease associated with long-term consequences, which has an extremely high prevalence in Iran. This condition results in a decline in the health of individuals following the use of improper coping skills caused by the effect of the psychological factor of the feeling of aging. In addition to physical problems, complications of diabetes impose costs on governments, which are both direct (medical care) and indirect (related to disability and early mortality). Over the last few decades, the psychological aspects of diabetes have been taken into account by several specialists, which is mainly due to the fact that diabetes is recognized as one of the most troubling chronic diseases in terms of emotional, cognitive, and behavioral aspects. Given the significant importance of the mental aspect of health in the elderly, evaluation of the health status of this group of people should not just be limited to the physical aspects. Evidence shows that mental factors, including psychological variables, not only affect the quality of life of people but also, they affect the result of coping with a chronic disease, especially in the area of diabetes care, which largely depends on social-mental factors for self-management, self-care and proper control of the disease. By affecting the perceptions of humans, psychological factors can affect the belief in the health and activities of individuals. Therefore, this study aimed to determine the relationship between the feeling of aging and functional independence in the elderly with type 2 diabetes at two diabetes centers in Boroujen, Iran.

Materials \& Methods: This cross-sectional, correlational, and descriptive study was performed on 123 elderlies aged 60-73 years, selected by convenience sampling. Following receiving a written consent, the Barthel questionnaire and brief aging perceptions questionnaire (B-APQ) were filled by the participants to evaluate their functional independence and feeling of aging (perception of aging), respectively. Data were collected through in-person interviews with the participants lasting for 20 minutes. Afterwards, data analysis was performed in SPSS version 16 using Pearson's correlation coefficient, independent t-test, and one-way analysis of variance $(\mathrm{P}<0.05)$.

Results: In this study, the mean and standard deviation of the total score of the feeling of aging was reported to be 58.21 \pm 7.5 , which showed an unfavorable feeling about the aging phenomenon. In this regard, the negative perception of aging included $16.1 \%$ of the participants. According to the results, there was a significant difference between the total score of perception of aging and other variables. In addition, Scheffe results demonstrated a significant difference between the mean score of perception of aging in the age group of 60-64 years with the age group of 70-74 years $(\mathrm{P}=0.001)$. However, there was no significant difference between other age groups in this regard. On the other hand, there was a significant difference between the mean score of perception of aging among those who lived alone with those who lived with their families $(\mathrm{P}=0.001)$ and between those who lived with their relatives and those living with their families $(\mathrm{P}=0.04)$. There was also a significant difference between the mean score pf perception of aging in the elderlies with unfavorable economic status and those with favorable economic status $(\mathrm{P}<0.001)$ and between the mean score of perception of aging of those with moderate economic status and those with favorable economic status $(\mathrm{P}=0.001)$. Our findings were indicative of a significant difference between the mean score of perception of aging in the elderlies whose health status was similar to others and those whose health status was better than others $(\mathrm{P}<0.001)$ and the elderlies whose health status was better than others with those whose health status was worse than others $(\mathrm{P}<0.001)$. The mean score of functional independence of the participants was $95.71 \pm 4.8$, and $52.8 \%$ and $11.4 \%$ of the subjects had slight and moderate dependence, respectively. According to the results of independent-test and one-way ANOVA, there was a significant difference between the total score of functional independence and all variables,
\end{abstract}

\footnotetext{
1. Professor, Department of Public Health Nursing and Geriatrics, School of Nursing and Midwifery, Iran University of Medical Sciences, Tehran, Iran (Corresponding author) Tel: $02143651800 \quad$ Email: bastani.f@iums.ac.ir

${ }^{2}$. MS, School of Nursing and Midwifery, Iran University of Medical Sciences, Tehran, Iran
} 
except for the level of education and other diseases. Moreover, Scheffe's results demonstrated a significant difference between all age groups in terms of the mean score of functional independence. Furthermore, a significant difference was observed between the mean score of functional independence of the elderly who lived alone with those who lived with their spouses $(\mathrm{P}=0.04)$. Nevertheless, no significant difference was found between the mean score of functional independence of other groups. In addition, there was a significant difference between the mean score of functional independence of the elderly with unfavorable economic status and those with favorable economic status $(\mathrm{P}=0.03)$. The results were also indicative of a significant difference between the mean score of functional independence in the elderly whose health status was similar to others and those whose health status was better than others $(\mathrm{P}=0.01)$ and between the elderly whose health status was better than others and those whose health status was worse than others $(\mathrm{P}<0.001)$. The results also demonstrated a significant, reverse association between the total score of functional independence and the total score of the feeling of aging $(r=0.37, \mathrm{P}<0.001)$.

Conclusion: According to the results of the present study, there was a significant, reverse relationship between the perception of aging and functional independence in the studied group. Therefore, recognition and understanding of such psychological factors and capacity and functional independence in different age groups can lead to policies related to the comprehensive health of the elderly and the design of preventive programs as a holistic care and educational interventions and counseling. Therefore, the perception of aging can be improved in this age group by empowering the elderly and increasing their functional independence. In order to reduce the negative feeling of aging, strategies such as education and empowerment counseling can strengthen the positive feeling of old age in them and promote them in order to enhance health and functional independence. Therefore, it is recommended that the relationship between two variables of perception of aging and functional independence be assessed in future research in the form of cohort studies. Furthermore, given the irreparable damage caused by chronic problems and diseases in old age, it is necessary to consider the relationship between functional independence of the elderly and other psychological factors in a greater spatial extent. Since a considerable number of our subjects were young elderly, it is suggested that further studies be performed on older elderlies. In addition, given the fact that the majority of the participants in the current research were married, and living with their families and received their support, it is recommended that other studies be performed on those who lived alone.

Keywords: Feeling of Aging, Functional Independence, Elderly, Diabetes

\section{Conflict of Interest: No}

How to Cite: Bastani F, Beigi Boroujeni P. The Association between the Perception of Aging and Functional Independence in the Elderly Patients with Type II Diabetes Mellitus. Iran Journal of Nursing. 2019; 32(117):722.

Received: 5 Jan 2019

Accepted: 8 Apr 2019 


\title{
ارتباط احساس بيرى با استقلال عملكردى در سالمندان مبتلا به ديابت نوع دو
}

\author{
*فريده باستانى '، بروانه بيكَى بروجنى '
}

جكيuه

زمينه و هدف: بيمارى ديابت با شيوع حدود ع/0 ميليون نفر در ايران، داراى ماهيت مزمن ييشرونده به همراه عوارض طولانى مدت است كه بـه دنبـال

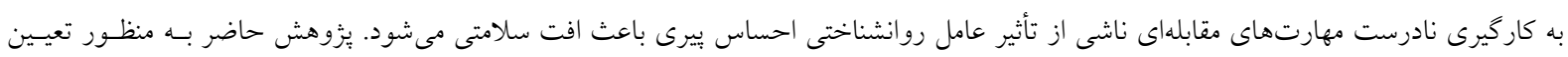

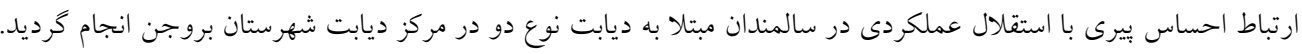

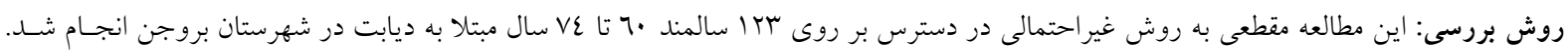

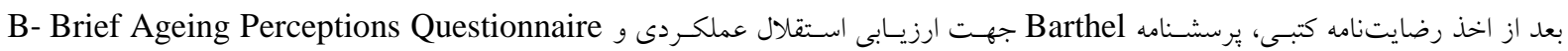

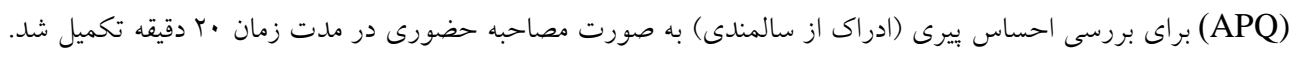

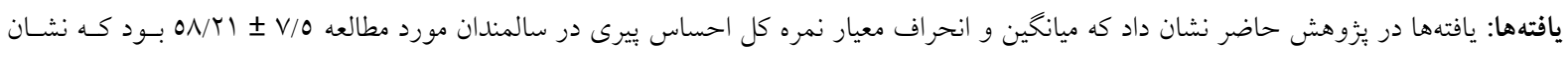

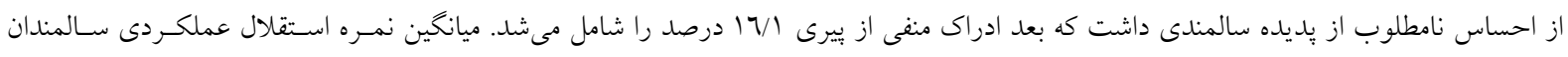

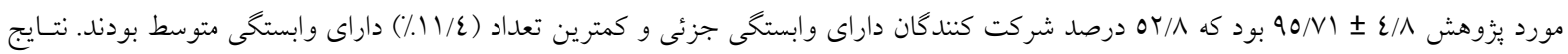

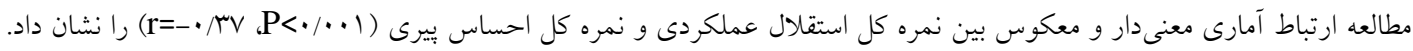
نتيجه گيرى كلى: با توجه به نتايج اين مطالعه كه ارتباط معنىدار و معكوسى را بين ادراى از سالمندى و استقلال عملكردى در كروه مورد مطالعه

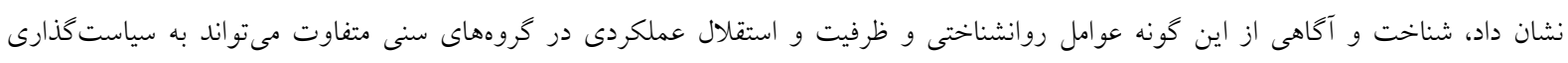

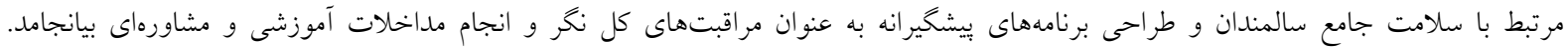

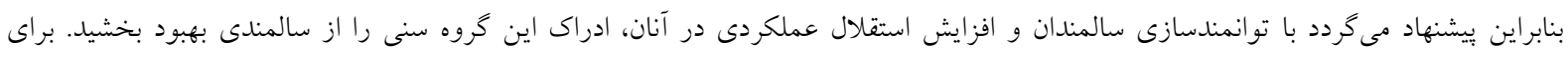

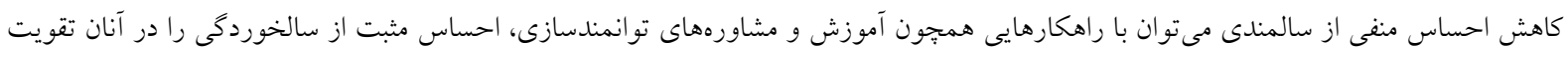

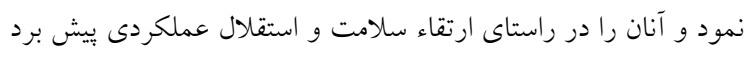
كليدوازهها: احساس بيرى، استقلال عملكردى، سالمند، ديابت تعارض منافع: ندارد تاريخ دريافت: 9V/1/1/ تاريخ بذيرش: 91/1/19

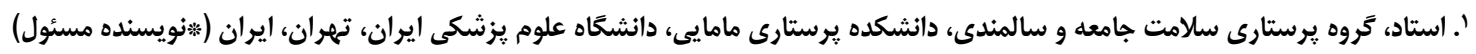
Email: bastani.f@iums.ac.ir

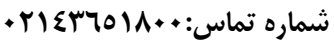
r. كارشناس ارشد، دانشكده يرستارى و مامايى، دانشكًاه علوم يزشكى ايران، تهران، ايران 
ديابت به عنوان يكى از بيمارىهـاى مـزمن برعارضـه در

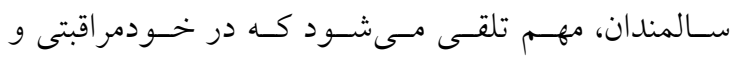

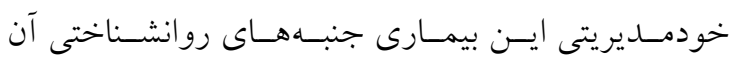

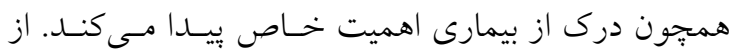

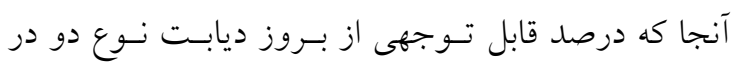

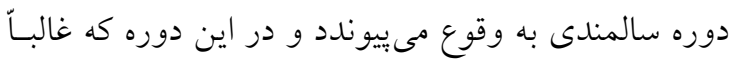

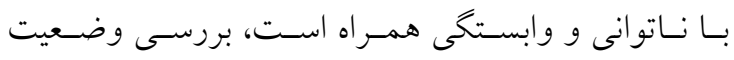

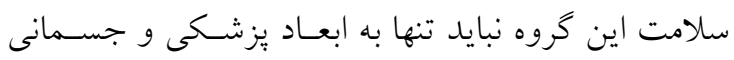

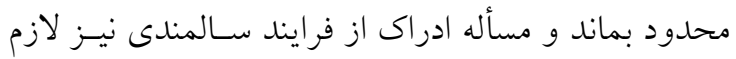
است مورد توجه قرار گيرد. در واقع، دسترسى نداشتن بـهـ اطلاعــات روانشــاختى و جامعـه شـناختى ديابـت در فر

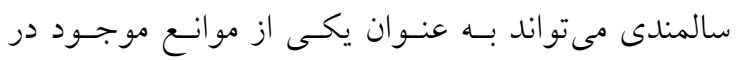

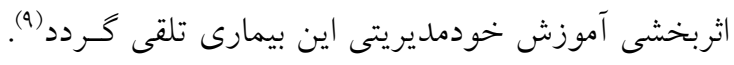

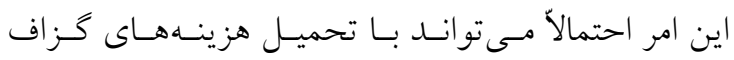

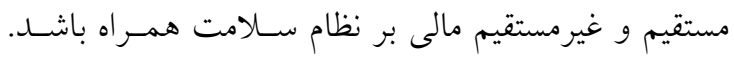

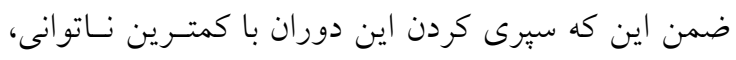

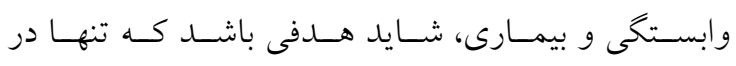

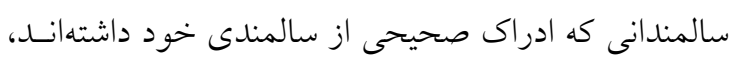

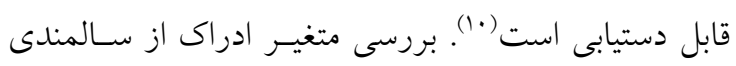

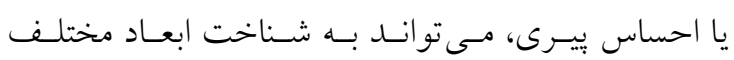

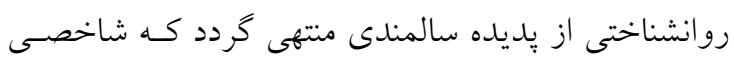

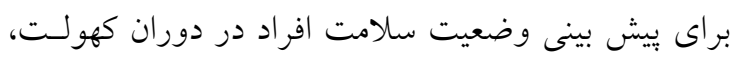

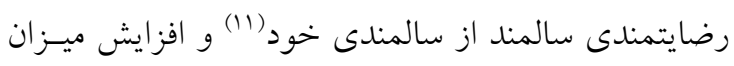

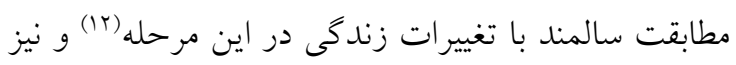

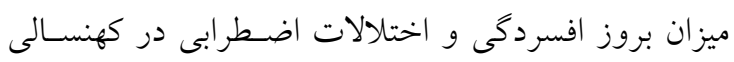

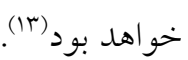
ديابت از اين نظر كه مستقيماً بر روى سـلامت تأثيركـذار بوده و به ايجاد ناتوانى و محدوديت عملكـردى ناشسى از

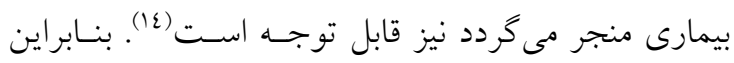

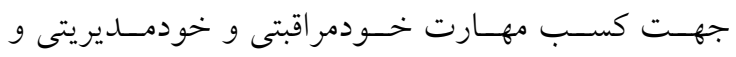

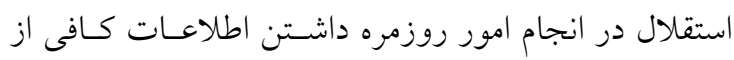

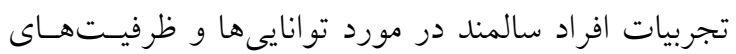

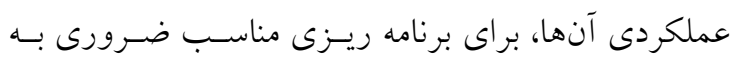

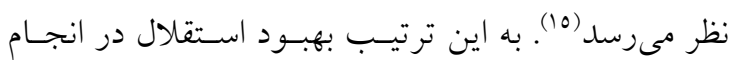

\section{مقدمه}

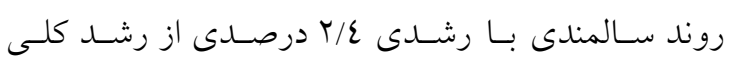
جمعيت كه 1/V درصد است بيشى كرفته و انتظار مىرود اين رشد در سالهاى آينده به // آ درصد برسد (1). يديـده

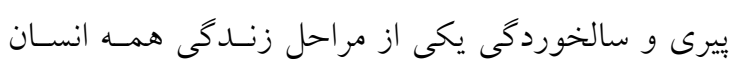

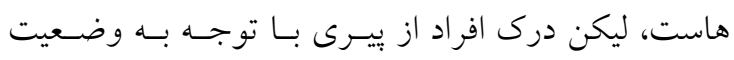
جسمانى، روانى و اجتماعى و ارتباطات بين فردى و بيش

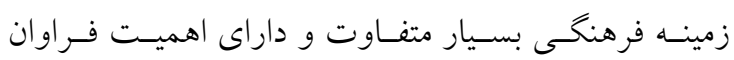

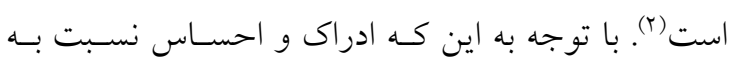
يديده يِيرى و سالخوردگى، تأثير به سزايى بر بهزيستى و

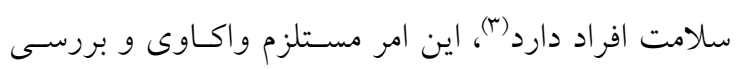
علمى بيشتر مىباشد. ضمن اين كه تحقيقات انجـام شـده در زمينه ادراك و احساس بيرى، عمـــتاً محسـدود بـوده و اعتقاد بر اين است كه برستاران و اعضاى گروه بهداشـى با انجام مطالعات وسيع تر بر اين بديده به حفـظ سـلامت سالمند و به ويزه افراد با بيمارىهاى مزمن كمك كـرده و

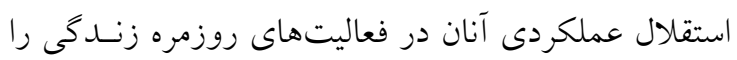
مورد يشتيبانى قرار دهند (ع). با توجه به اين مهم كـه يكسى از شايعترين مشكلات جسمى در دوران سالمندى بيمارى مزمن ديابت است كه حدود r ماع ميليون نفـر رادر سـال عا +r در جهان دركير نموده(0) و بيش بينى مسى شـود كـه

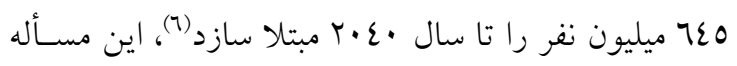
از شدت و حساسيت بيشترى برخــوردار اسـت. در طـول دهاهـاى گذشته، جنبه هاى روانشناختى ديابـت نيـز نظـر بسيارى از متخصصان را به خود جلب كـرده اسـت زيـرا ديابت، يكى از گريبان كيرترين بيمارىهاى مزمن از لحاظ

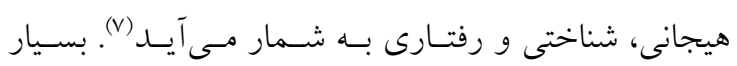
مشاهله شده است كه عوامل ذهنى و از آن جمله عوامـل فئل روانشناختى نه تنها بر كيفيت زندكى افراد، بلكه اغلب در مشخص شدن نتيجه مقابله با يك بيمارى مزمن، بـه ويـزّه

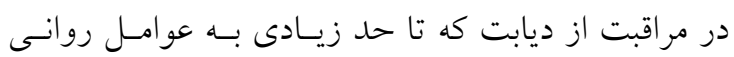
اجتماعى فرد براى خودمديريتى، خــودمراقبتى و دسـتيابى به كنترل مناسـب ايسـن بيمـارى وابسـته اسـتـ، تأثير گــذار هستند (^). 


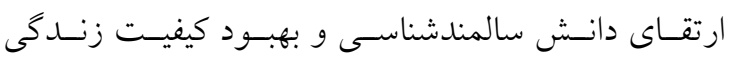

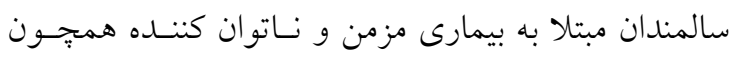

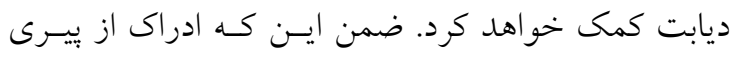
يكى از مفاهيم كاربردى در علـم سالمندشناسى و علـوم

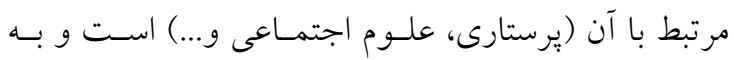
عنوان يكى از حلقههاى مهم مرتبط با مشكلات سالمندان

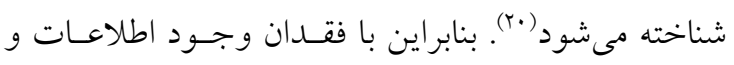
شواهد علمسى، مطالعه، حاضـر بــا هـــف تعيـين ارتبـاط احساس ويرى با استقلال عملكردى در سالمندان مبتلا بـهـ ديابت نوع دو انجام كرديد.

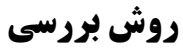

اين يزوهش يكى مطالعه از نوع همبستكى - توصيفى

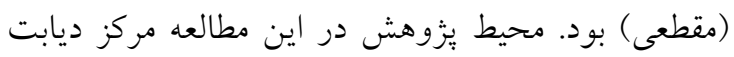

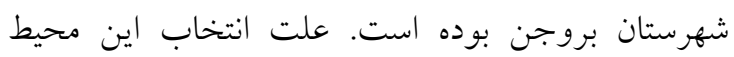

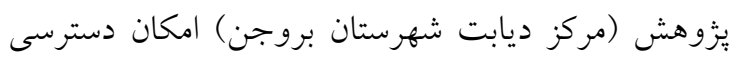

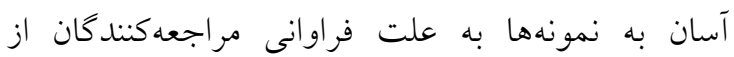

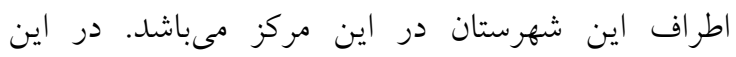
تحقيق، جامعه يزوهش را تمامى سالمندان مبتلا به ديابت

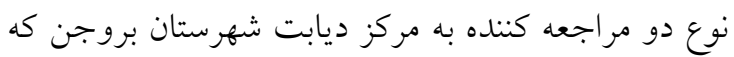

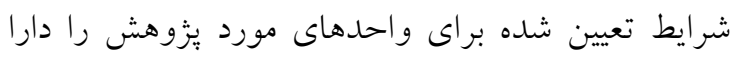

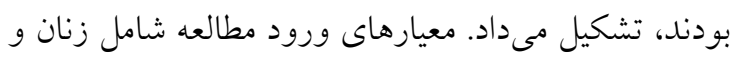
مردان سالمند .7 تا ع Vال مبتلال به ديابت نوع دو، قادر به راه رفتن مستقل با يا بدون وسايل كمكى، دارا بودن

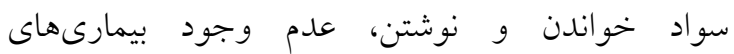
روانيزشكى (با مراجعه به يُرونده بيماران)، نداشتن اختلال

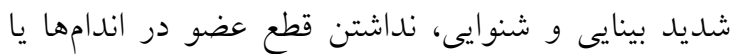
يروتز، نداشتن ناتوانى نورولوزيكى يا عصبى به استناد يرونده سالمند بوده است. لازم به ذكر است كه سالمندان مبتلا به ديابت طبق برنامه كارى مركز به صورت ماهانه جهت دريافت مشاورههاى يزشكى تغذيهاى و مراقتى

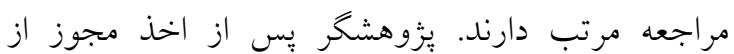

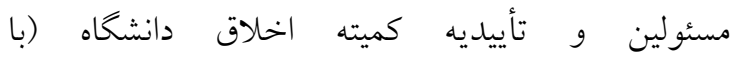

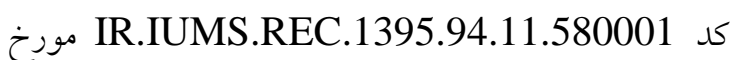

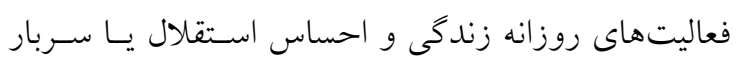

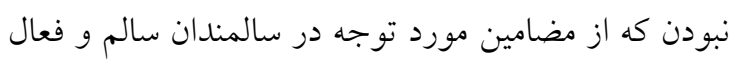

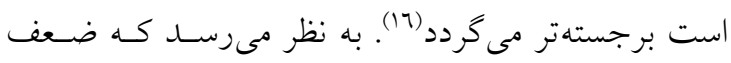

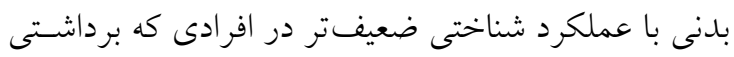

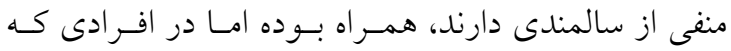

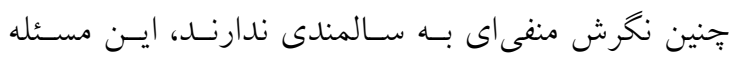
صدق نمى كند (IV).

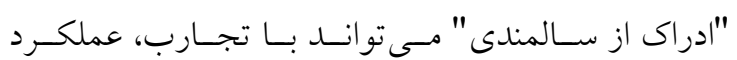
شناختى، سلامت روانى و جسمانى افـراد سـالمند ارتبـاط داشته باشد و منجر به تغييرات اجتناب نايذيرى كردد (1).

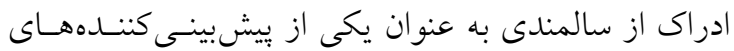
ناتوانى عملكردى در سالمندان معرفى شــده اسـت. يافتـه

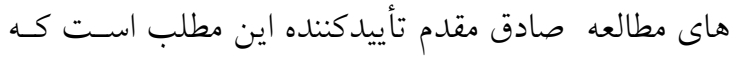

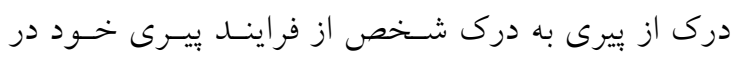

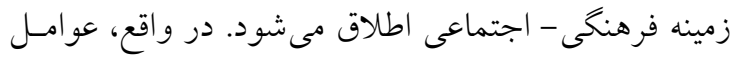

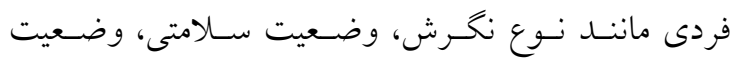

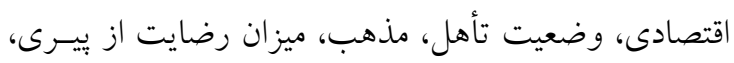

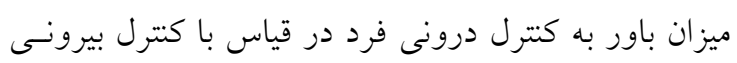

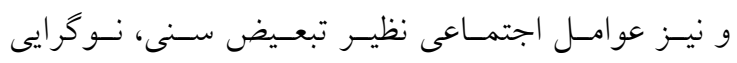

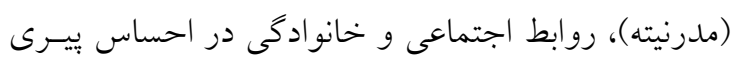

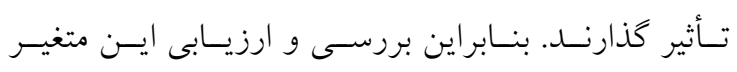

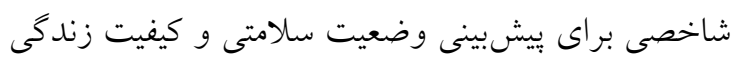

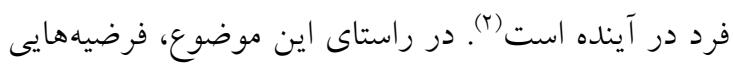

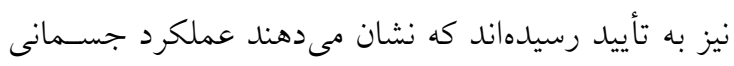
و خودينداره، هـر دو يـك مكانيسم روانسى مشـترك بـهـ

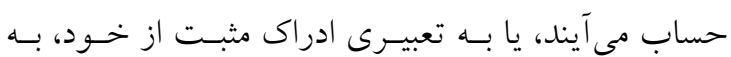

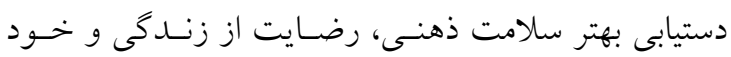
امتيازدهى سلامتى منجر مىشود (19).

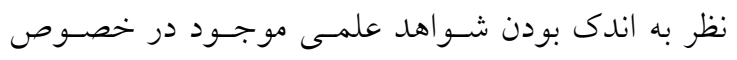
ارزيابى ادراك از سالمندى يا احساس ييرى در سـالمندان ايرانى، مطالعه در مورد ايـن مبحــث مسىتوانـــ اطلاعـات

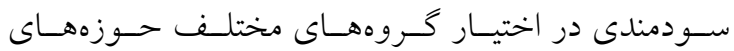
بهداشتى - درمانى، آموزشى و اجتماعى ارائه نمايد. انجـام

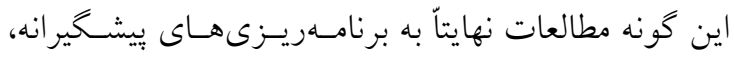


لباس يوشيدن، كنترل ادرار و مدفوع، انتقال از صندلى بـــ

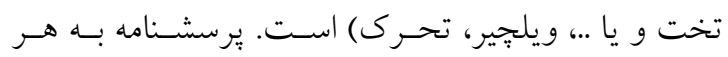

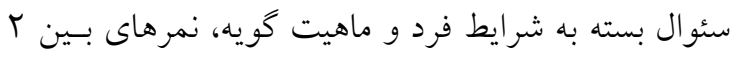

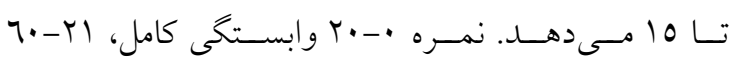

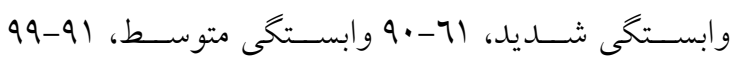

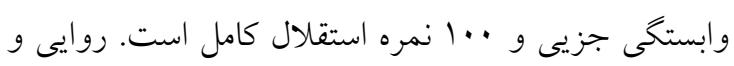

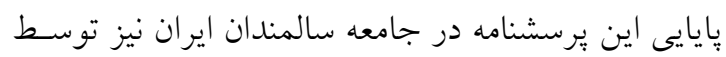
تقبى و همكاران انجام كرفته است و ثبات داخلسى ابـزار از طريق آلفاى كرونباخ 97/. محاسبه شده است (rr).

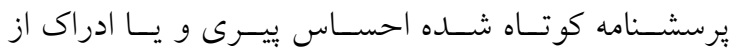

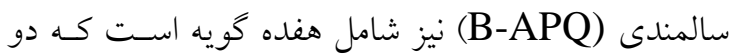
بعد كيفى و كمى را شامل مىشود. در بخـش كمسى، يـنسج

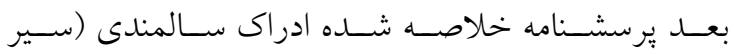
بيشرونده سالمندى، نتايج مثبـت، كنتـرل مثبـت، نتـايج و

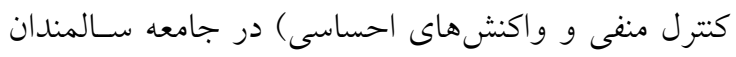

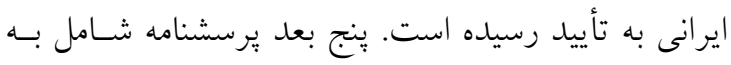

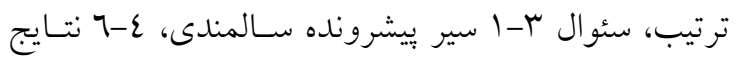
مثبت سالمندى، V-9 كنترل مثبت، • •l-ع ا نتايج و كنتـرل

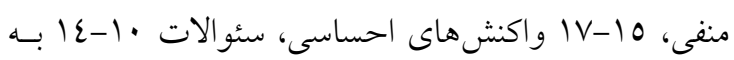

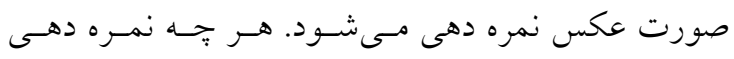

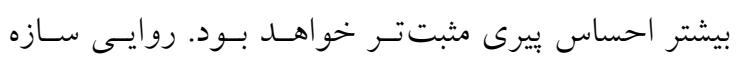

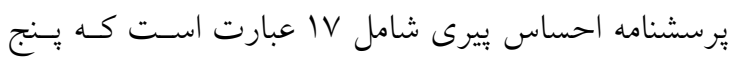
حيطه احساس بيرى را در سـالمندان مشـخص مسى كنـد.

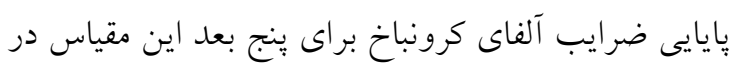

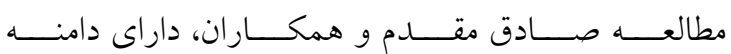


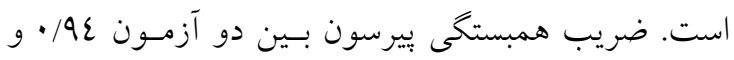

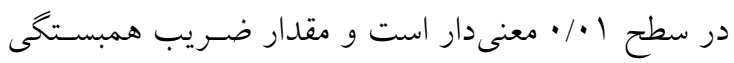

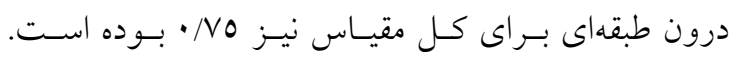

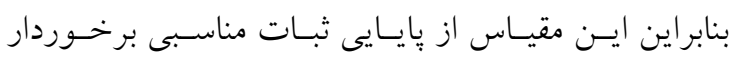

يافتهاى يززوهش حقى عسخرآبادى و همكاران كه ويزگكىهاى روانسنجى اين ابزار را مورد بررسى قرار داده

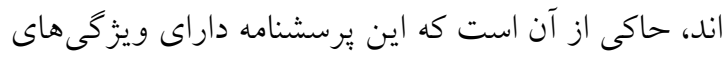

90/0/17) و توضيحات لازم به مسئولين ذيربط و تكميل

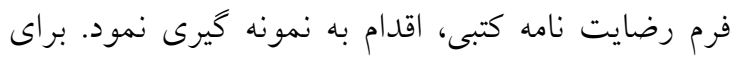

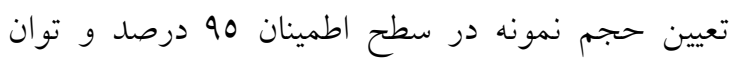

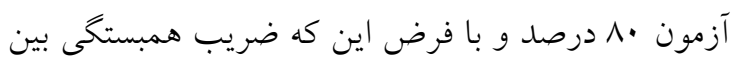

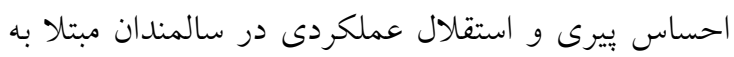

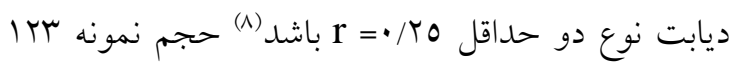
نفر برآورد كرديد. ابزارهاى مورد استفاده در اين مطالعه شامل فرم اطلاعات

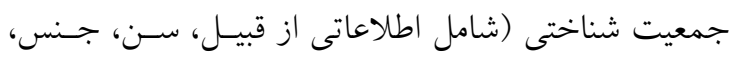

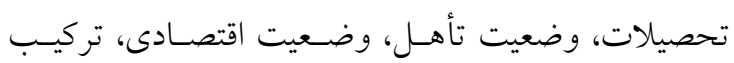

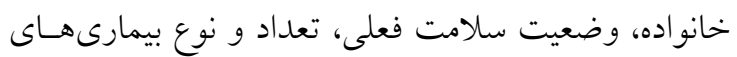

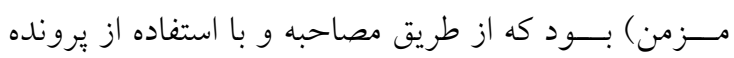

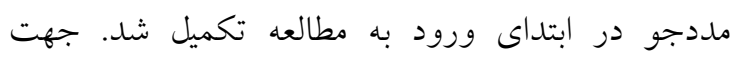

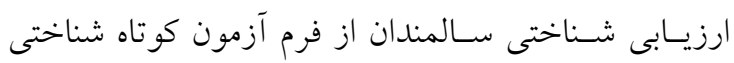
كه حساوى ده سـئوال (Abbreviated Mental Test)

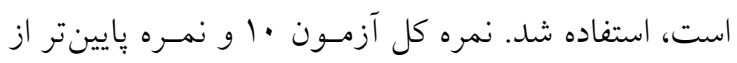

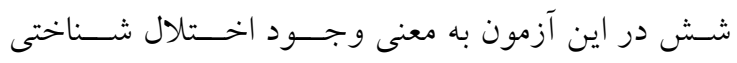

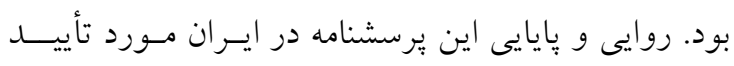

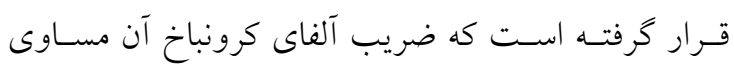

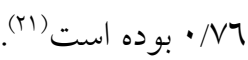

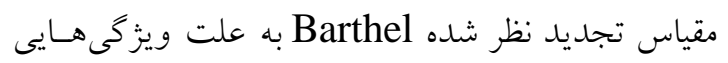

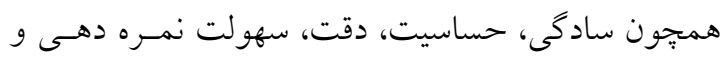

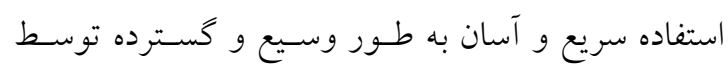
يُزوهشخران و كاركنان بهداشتى درمانى مورد استفاده قرار كرفته است. نسخه اوليه اين ابزار Original Barthel)

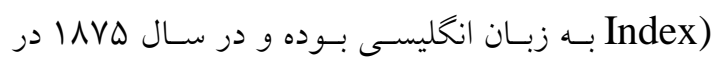
امريكـا توسط Florence Mahoney, Dorothea Barthel طراحسى شـــه اسـت. ابـزار Barthel داراى توسط

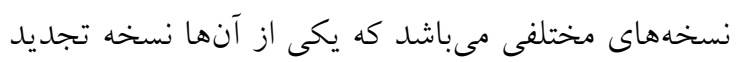

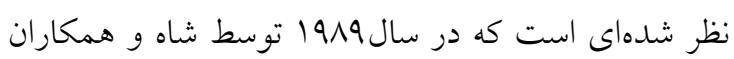

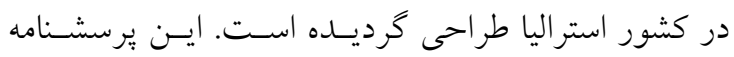
جهت بررسى فعاليتهاى روزمره زندگى استفاده مى شـود و حساوى لالكويسه (بهاشــت فـردى، حمـام كـردن، غذاخوردن، استفاده از دستشويى، بالاو و پايين رفتن از رِّله، 
يُزوهشكر با مراجعه به مركز ديابت بروجن، ضـمن بيـان

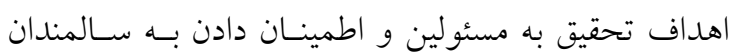

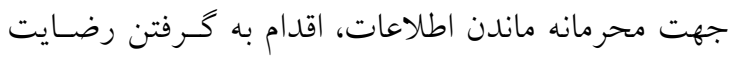

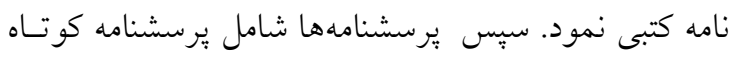

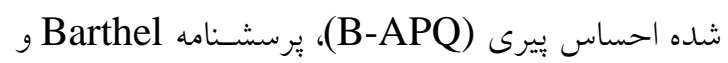

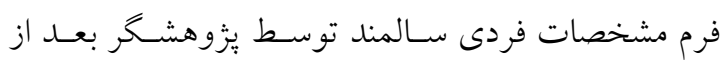

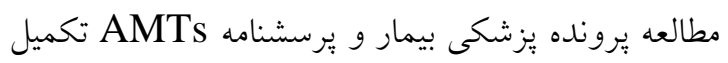

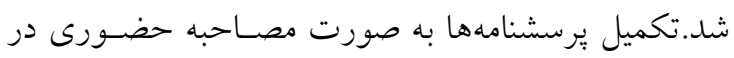
مدت زمان حدود لها الى •r دقيقه انجام كرفـت. نمونسه

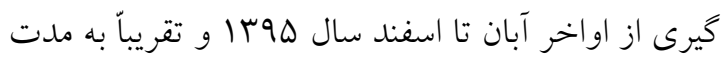
جهار ماه طول كشيد. بعد از كردآورى برسشنامهها، تجزيه

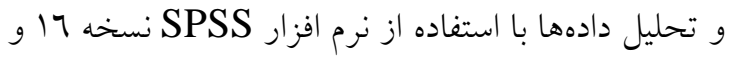
با استفاده از روشهاى آمار توصيفى مانند تنظيم جــداول

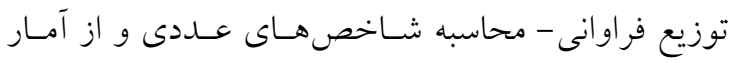
اسـتنباطى و آزمـون هــاى كـاى دو، تـى مسـتقل، آنـاليز

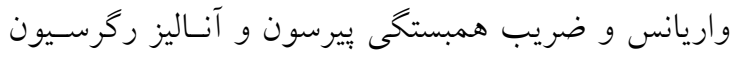

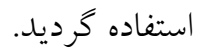

\section{يافتهها}

ميانخين سنى سالمندان شركت كننده در ايسن مطالعـه و/9 ع

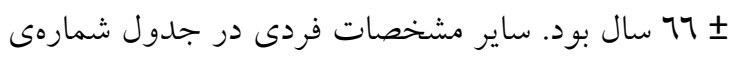

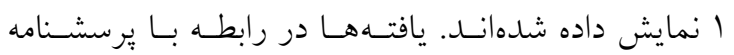
احساس وييرى نشان داد كه ميانخين و انحر اف معيار نمـره

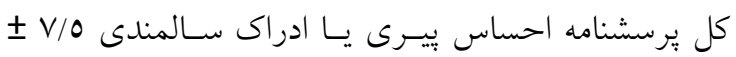

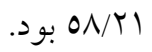

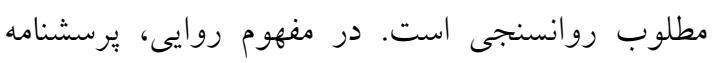

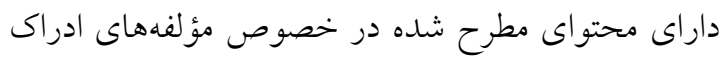

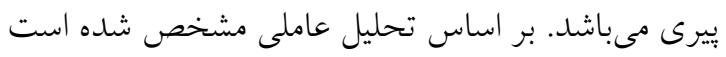

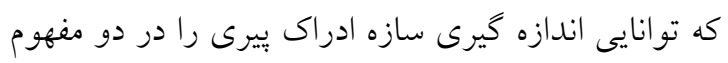

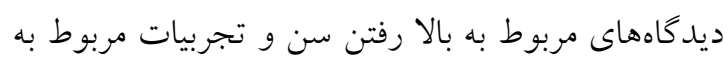

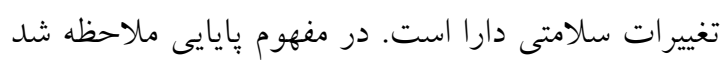

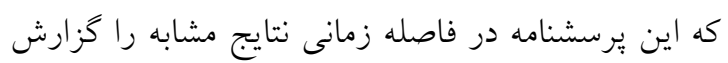

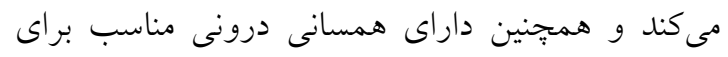

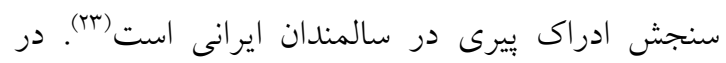
مطالعهى حاضر، يُزوهشخر ييش از انجام نمونه كيرى،

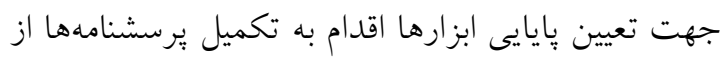

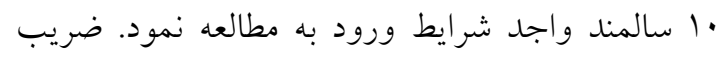

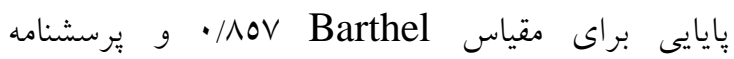

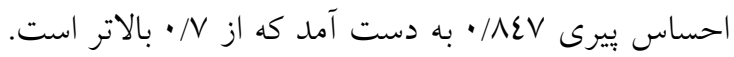

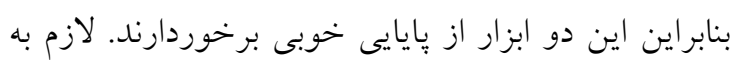

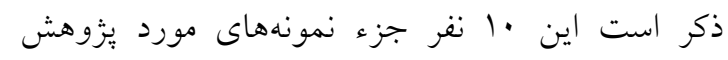

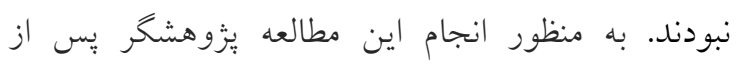
تصويب يرويوزال و اخذ اجازه از كميته اخلاق دانشعاه إنهاه

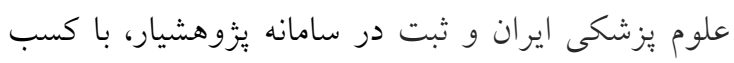

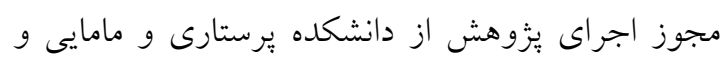

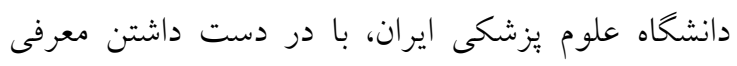

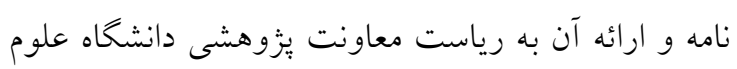

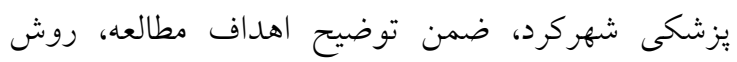

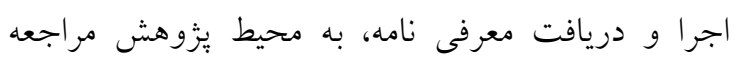
نمود. 
جدول شماره (: مشخصات فردى نمونههاى مورد مطالعه

\begin{tabular}{|c|c|c|c|}
\hline درصد & 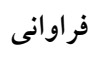 & \multicolumn{2}{|c|}{ متغير } \\
\hline$\varepsilon 1 / 0$ & 01 & مرد & جنسيت \\
\hline$O N / O$ & VT & 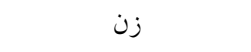 & \\
\hline $7 r / 7$ & vV & زيردييلم & \\
\hline$r \mu / \tau$ & rq & دييلم & ميزان تحصيلات \\
\hline $\mid r / \Lambda$ & iv & تحصيلات دانشگاهى & \\
\hline$v \varepsilon / \Lambda$ & $9 T$ & متاهل & وضعيت تاهل \\
\hline rO/r & $\mu_{1}$ & بدون همسر & \\
\hline $17 / r$ & r. & تنها & \\
\hline$r q / r$ & m & با همسر & تركيب زندكى \\
\hline $0 . / 2$ & $\pi$ & با خانواده & \\
\hline$\varepsilon / 1$ & 0 & با بستخان & \\
\hline$r \mu / \tau$ & rq & ضعيف & \\
\hline $0 . / 2$ & $\pi$ & متوسط & وضعيت اقتصادى \\
\hline rฯ & rt & خوب & \\
\hline$r T / 0$ & $\varepsilon$. & بهتر از ديكران & \\
\hline$r \cdot / q$ & r & مانند ديخران & وضعيت سلامتى \\
\hline$r q / 7$ & ¿o & بدتر از ديكران & \\
\hline$r \cdot / 9$ & $\mu_{\Lambda}$ & قلبى & \\
\hline $\mathrm{u} / \mathrm{r}$ & $\wedge \varepsilon$ & فشار خون بالا & \\
\hline $7 \cdot / r$ & $v \varepsilon$ & بيمارى هاى مفصلى & وضعيت بيمارى زمينه اى \\
\hline$\varepsilon \cdot / V$ & 0. & بيمارى هاى كوارشى & \\
\hline$|V /|$ & r & بيمارى هاى تنفسى & \\
\hline$N / 9$ & 11 & ساير & \\
\hline
\end{tabular}

معيار نمره كل احساس بيرى در بعد نتايج و كنترل منفى

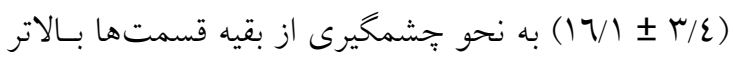

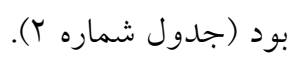

يافتها در رابطه با يرسشنامه احساس بيرى نشان داد كـه

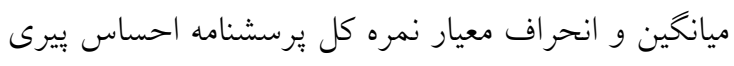

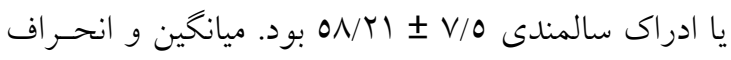

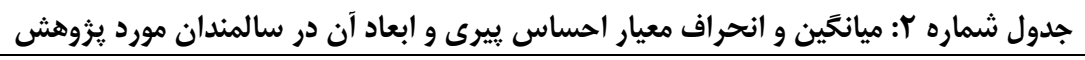

\begin{tabular}{|c|c|c|c|c|}
\hline حداكثر ل & حداقل & انحر اف معيار & ميانخين & احساس بيرى \\
\hline 10 & 0 & $1 / V$ & 11 & نتايج مثبت \\
\hline 10 & 7 & 1/0 & 11 & كتترل مشبت \\
\hline$r r$ & 0 & $r / \varepsilon$ & $17 / 1$ & نتايج و كتترل منفى \\
\hline 10 & r & $r / r$ & $1 \cdot / r$ & سير ييشرونده \\
\hline 10 & r & $r / 9$ & $9 / 7$ & واكنشهاى احساسى \\
\hline$v r$ & rT & $V / 0$ & $O N / T)$ & نمره كل \\
\hline
\end{tabular}




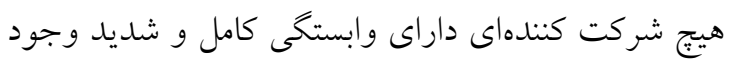

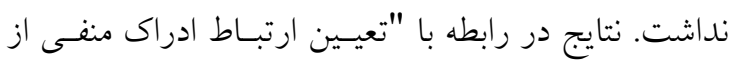

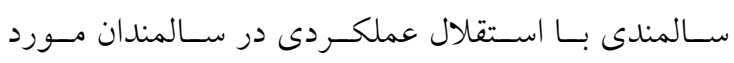
"يزوهش - مبتلا به ديابت نوع دو" (جدول شماره ع) نشان

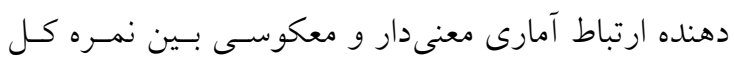

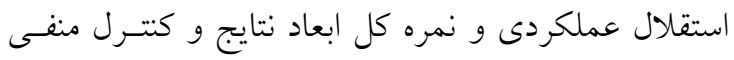

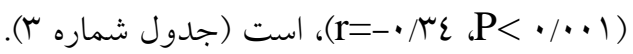

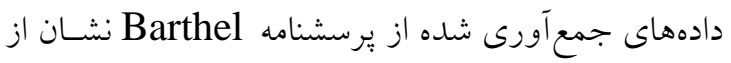
آن داشت كه ميانخين نمره استقلال عملكـردى سـالمندان أنسان

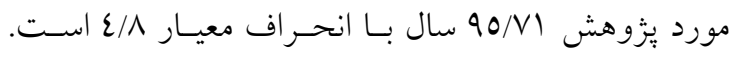

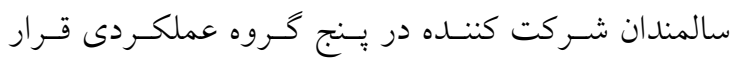

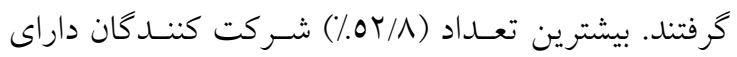

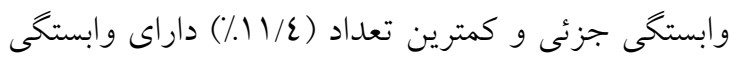
متوسط بودند (جدول شماره r).

جدول شماره بّ: توزيع فراوانى مطلق و نسبى استقلال عملكردى سالمندان مورد يزوهش سال 90

\begin{tabular}{|c|c|c|}
\hline مدرد & 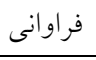 & استقلال عملكردى \\
\hline $11 / \varepsilon$ & $1 \varepsilon$ & وابستگى متوسط (ال7 تا •و) \\
\hline$O r / \Lambda$ & 70 & وابستكى جزيى (91 تا 99) \\
\hline ro/1 & $\varepsilon \varepsilon$ & بدون وابستخى ( · (1) \\
\hline $1 \cdots$ & Ir & جمع \\
\hline \multicolumn{2}{|c|}{$90 / N 1 \pm(\varepsilon / 1)$} & ن ماه كل \\
\hline \multicolumn{2}{|c|}{$\mathrm{V} 7$} & حداقل \\
\hline \multicolumn{2}{|c|}{$1 \ldots$} & حداكثر \\
\hline
\end{tabular}

جدول شماره ع: ضريب همبستكى بيرسون بين احساس بيرى (در بعد ادراك منفى از سالمندى) با استقلال عملكردى سالمندان مورد

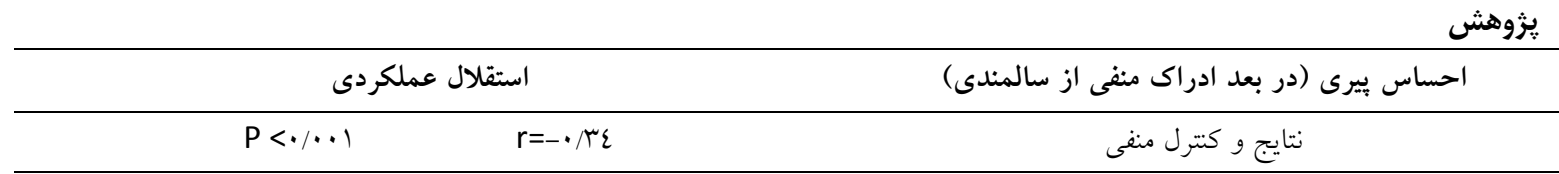

بين مقادير واقعى و مقادير بيش بينى شده

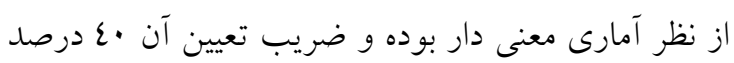

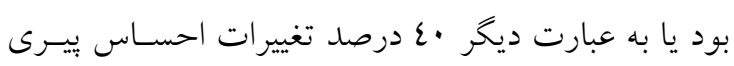
توسط متغيرهاى فوق قابل تبيين است.

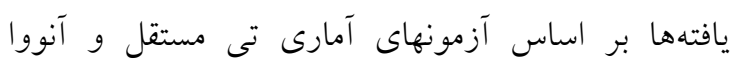
يكطرفه به غير از متغيرهاى سطح تحصيلات و ساير إنساي

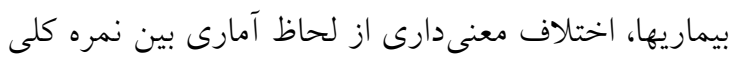
استقلال عملكرد و ساير متغيرها وجود داشت (جدول

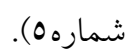

يافتها در مورد ارتباط احساس بيرى و سـاير متغيرهـاى

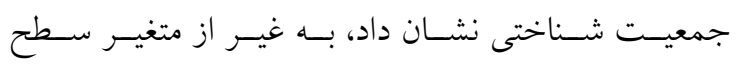

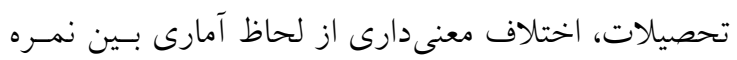

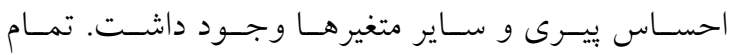

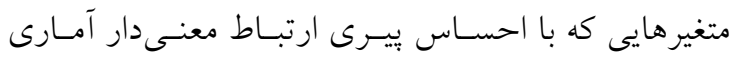

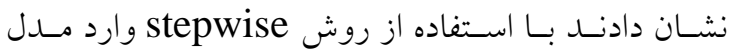

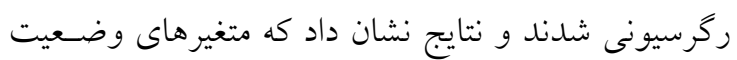

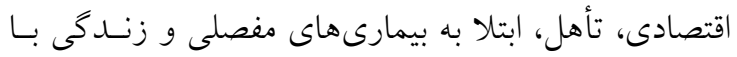

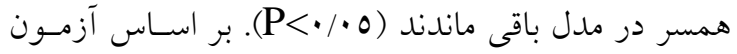
هاى آمارى رگرسيون خطى جنا مند متغيره ضريب همبستخى 


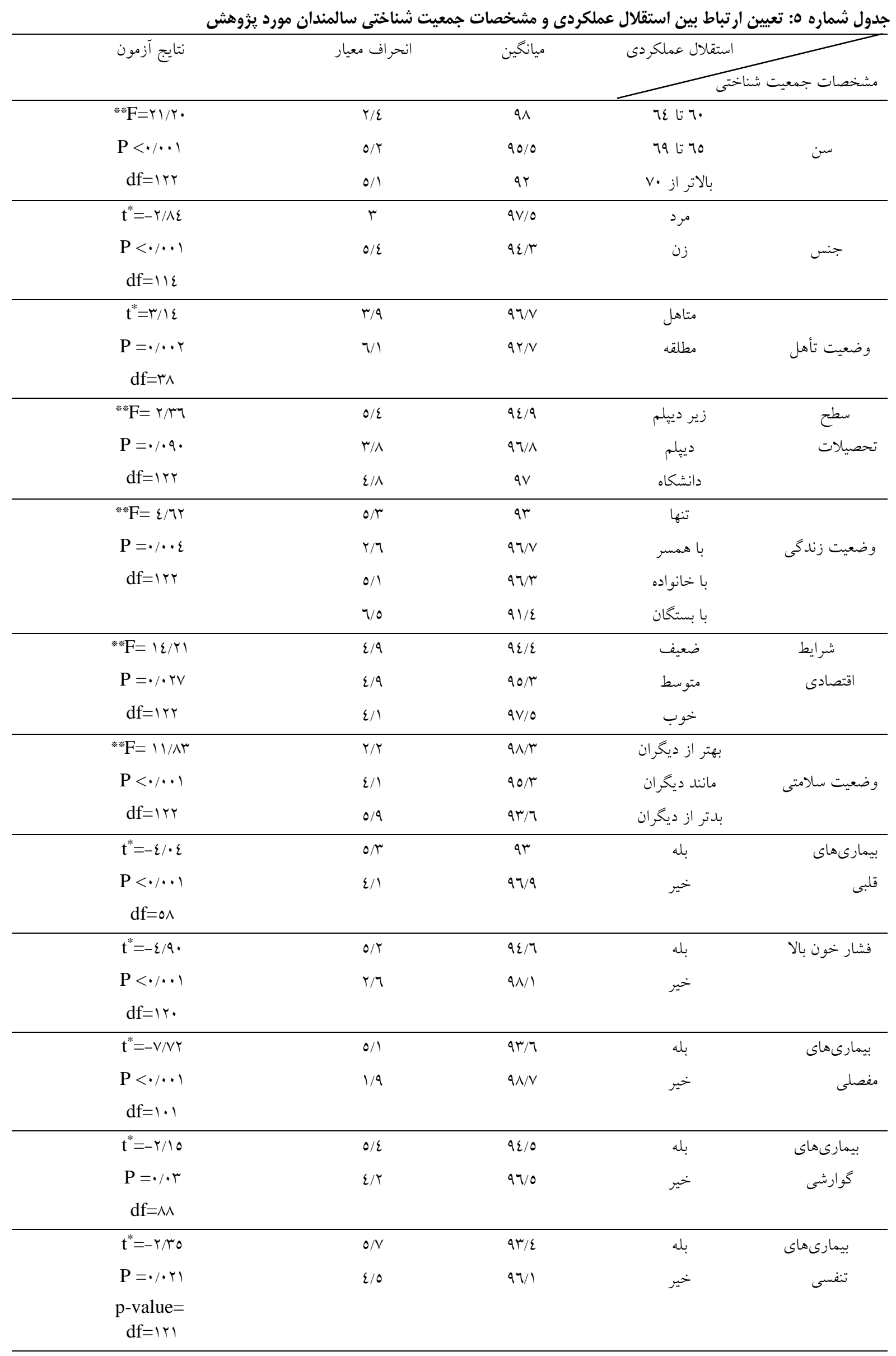




\begin{tabular}{|c|c|c|c|c|}
\hline$t^{*}=-1 / \cdot 1$ & $V / 7$ & $94 / 0$ & بله & ساير \\
\hline $\begin{array}{c}P=\cdot / \mu \\
d f=1\end{array}$ & $\varepsilon / 0$ & $90 / 9$ & خير & \\
\hline$t^{*}=7 / 77$ & $r / \varepsilon$ & $97 / 1$ & بله & استقلال \\
\hline $\begin{array}{c}\mathrm{P}<\cdot / \cdot \cdot 1 \\
\mathrm{df}=10\end{array}$ & $0 / \varepsilon$ & $\Lambda V / T$ & خير & \\
\hline
\end{tabular}

$$
\text { *قآزمون تى مستقل }
$$

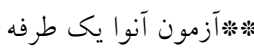

مىكردند از نظر آمارى اختلاف وجود داشت (ع (P=•). ولى ميانخين نمره استقلال عملكردى در ساير خروهها اختلاف معنى دار آمارى نداشتند. در واقع، نتايج آزمون تعقيبى شفه نشان داد كه بين ميانخين نمرات استقلال عملكردى در سالمندانى كه وضعيت اقتصادى ضعيف

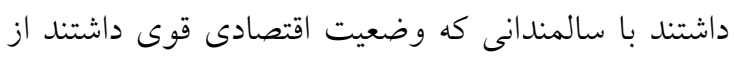

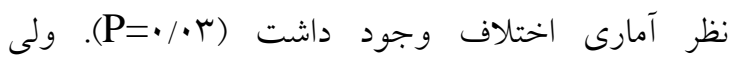

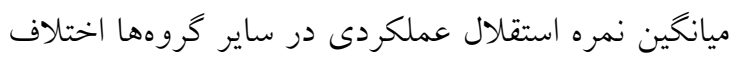

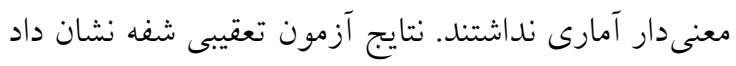
كه بين ميانخين نمرات استقلال عملكردى در سالمندانى

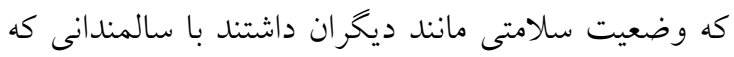

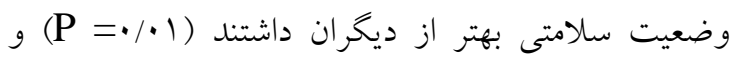
سالمندانى كه وضعيت سلامتى بهتر از ديخران داشتند با ناس سالمندانى كه وضعيت سلامتى بلدتر از ديخران داشتند از نظر آمارى اختلاف وجود داشت ( (P</. P). كليه متغير هايى كه مطابق جدول شماره 0 با استقلال عملكرد ارتباط stepwise معنى دارآمارى نشان دادند با استفاده از روش وارد مدل ركرسيونى شدند و نتايج نشان داد كه متغيرهاى فوق در مدل باقى ماندند. بر اساس رگرسيون خطى جند متغيره ضريب همبستكى بين مقادير واقعى و مقادير بيش بينى شده MVT/ بود كه از نظر آمارى معنادار بوده و

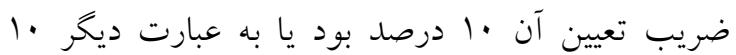
درصد تغييرات استقلال عملكردى توسط متغيرهاى فوق قابل تبيين است. ميانخين نمرات استقلال عملكردى در سالمندانى كه كابين

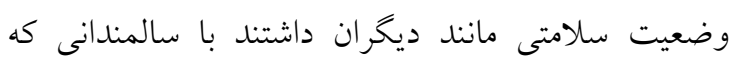

نتايج آزمون تعقيبى شفه نشان داد كه بين ميانخين نمرات

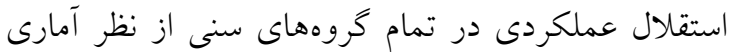
اختلاف معنىدارى وجود داشت. بعبارتى، بين متغير لمائ استفلال عملكردى با سن ( F تفاوت معنىدار بوده بطورى كه در سالمندان بين سنين .7 تا ع 7 سال، استقلال نسيت به سنين بالاتر (70 تا 79

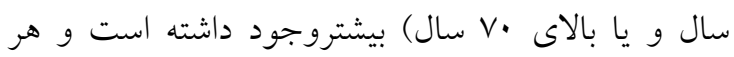
جهه سن رو به افزايش كذاشته استقلال عملكردى كاهش داشته است. هم جنين بين متغير استقلال عملكردى و و

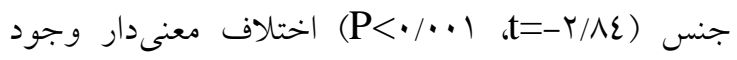

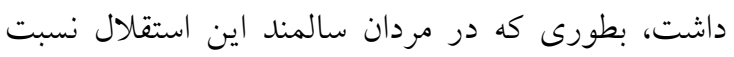
به زنان بيشتر بوده است. بعلاوه استقلال عملكردى در

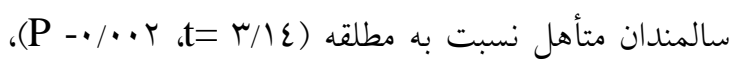
سالمندانى كه با همسر خود زندكى مى كردند نسبت به سالمندان تنها و بدون همسر ( سالمندانى كه شرايط اقتصادى خوب داشتند نسبت به كسانى كه وضع بد يا ضعيف اقتصادى را دارا بودند

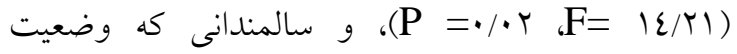

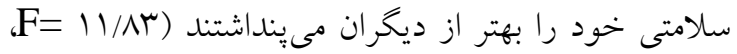

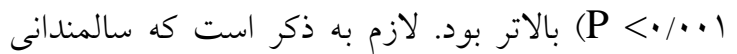
كه فاقد بيماريهاى قلبى، يُر فشارى خون، بيمارىهاى

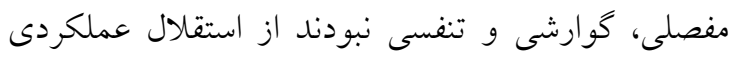
بالايى نسبت به سالمندانى كه اين بيمارىها را دارا بودند

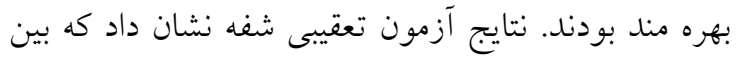

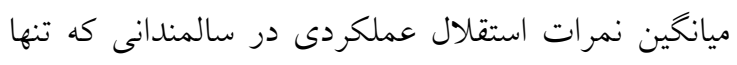

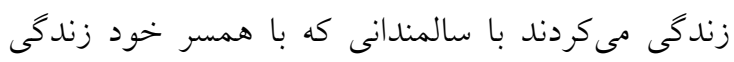


اساس ركرسيون خطى جنند متغيره ضريب همبستكى بين

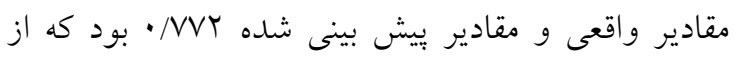

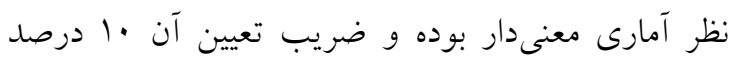
بود يا به عبارت ديخر لما درصد تغييرات استقلال عملكردى توسط متغيرهاى فوق قابل تبيين است (جدول

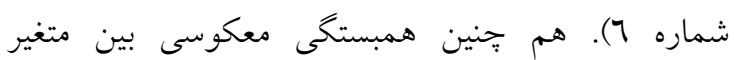

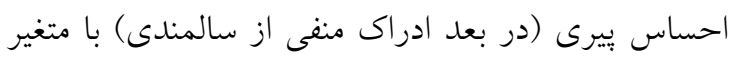

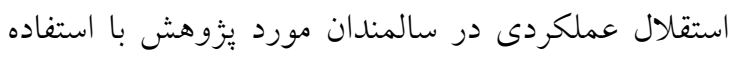

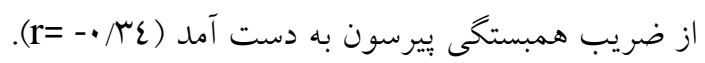

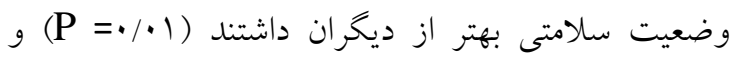
سالمندانى كه وضعيت سلامتى بهتر از ديخران داشتند با دانيا

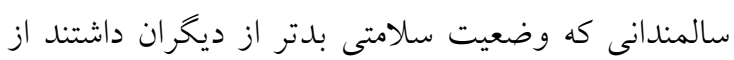

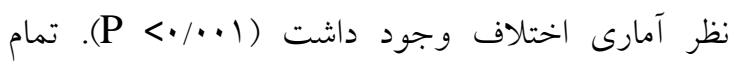

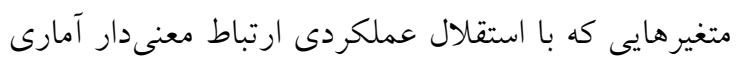

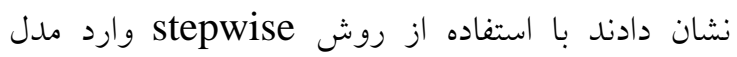
ركرسيونى شدند و نتايج نشان داد كه متغيرهاى مستقل

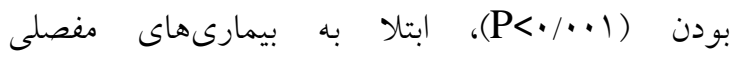
(P<•/..1)

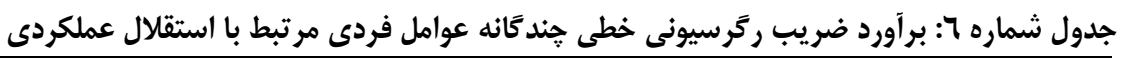

\begin{tabular}{|c|c|c|c|c|}
\hline نتايج آزمون & $\mathbf{R}$ & ضريب استاندارد & B & عوامل بيش بينى كننده \\
\hline $\mathrm{P}<\cdot / \cdot \cdot 1$ & $\cdot / 7 \varepsilon q$ & $\cdot / 7 \varepsilon$ & $9 / 7 T$ & مستقل بودن (مبنا: وابستكى) \\
\hline $\mathrm{P}<\cdot / \cdot \cdot 1$ & $\cdot / V \varepsilon \varepsilon$ & $-\cdot / \mu V$ & $-r / N r$ & ابتلا به بيمارى هاى مفصلى \\
\hline $\mathrm{P}=\cdot / \cdots 1$ & $\cdot / V V Y$ & $-\cdot / r \mu$ & $-\cdot / T r$ & سن \\
\hline
\end{tabular}

بيشتر سالمندان مورد يزوهش داراى سطح سواد كمتر از ديبم بوده و وضعيت اقتصادى مطلوبى نداشتند اين يافته لئه مى تواند قابل توجيه باشد. نتايج در مبحث احساس بيرى هم نشان داد، نمره كسب شده از متغير احساس بيرى در بعد نتايج و كنترل منفى با ميانخين |l/1 و انحراف معيار ع/r نسبت به ديخر ابعاد اين متغير بيشتر بوده است. اين يافته با نتايج مطالعات

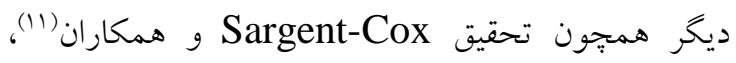

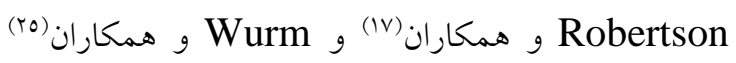
همخوانى دارد. به طور كلى، احساس بيرى يا ادراك از سالمندى، شاخصى براى رضايت هر فرد از بيرى خود و بازتابى از تطابق فرد با تغييرات مرتبط با سالمندى است

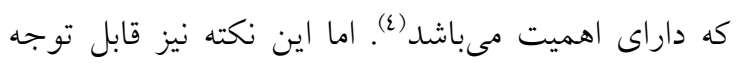
است كه سالمندان، جزو اقشار ناهمكن در تحقيقات محسوب مىشوند و موضوع احساس بيرى تحت تأثير عوامل مختلف و متعددى از قبيل متغيرهاى اقتصادىاجتماعى و روانى است كه واكاوى جامعتر و عميقترى را در اين باب مىطلبد.

\section{بحث و نتيجه تيرى}

در اين مطالعه مقطعى، يافتهها نشان داد كه ميانخين سنى سالمندان شركت كننده I7/1 سال با انحراف معيار ع/9 بود كه بيانكر طبقهاى از سالمندى جوان است (و نه سالمندان بير). در خصوص وضعيت سالمتى سالمندان مورد مطالعه كه مبتلا به ديابت بودند، نتايج نشان داد حدود يك سوم وضعيت سلامتى خود را بدتر از ديخران مىدانستند و برداشت مثتى از وضع سلامتى خود نداشتند. در حالى كه در مطالعه Robertson و همكاران(IV) اين ميزان به دو سوم مىرسيد كه از اين نظر متفاوت با نتايج يزوهش ما بود كه اين امر مىتواند به علت تمايز در سبك زندگى، سطح تحصيلات، درآمد، دسترسى به مراقبتهاى بهاشتى - درمانى، وضعيت رفاهى و كلاً كيفيت زندگى در جوامع بيشرفته و در حال توسعه باشد. براى مثال، سالمندانى كه داراى سطوح بايين تر سواد بوده و درآمد كمترى در زندكى داشتهاند

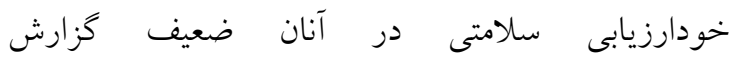

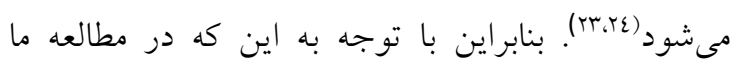




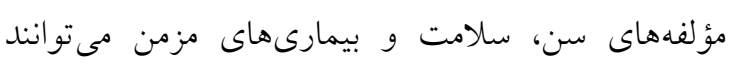

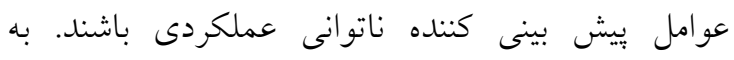

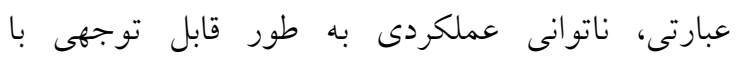

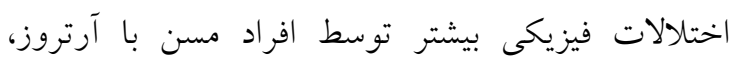

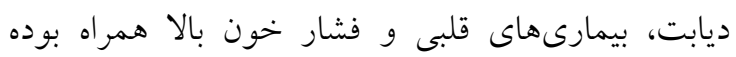

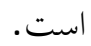

در خصوص متغير احساس بيرى در بعد ادراى منفى از سالمندى با استقلال عملكردى در سالمندان مبتلا به

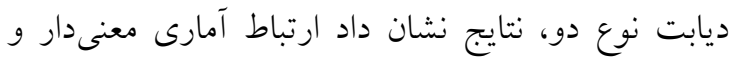
معكوسى بين نمره كل استقلال عملكردى و نمره كل ابعاد نتايج و كنترل منفى وجود داشت. اين يافته در راستاى لمره

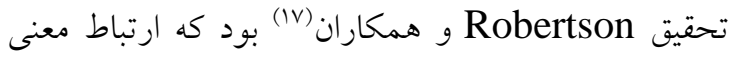
دارى را بين ادراك منفى از بديده يِيرى و عملكرد اجرايى

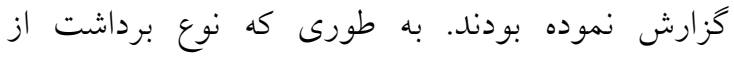

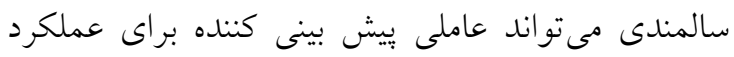

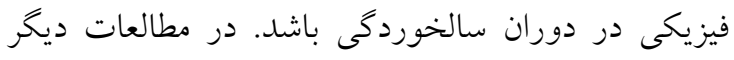

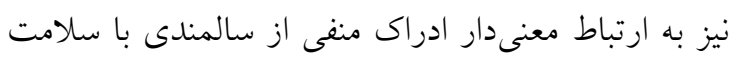

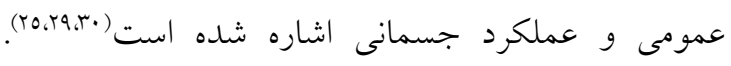

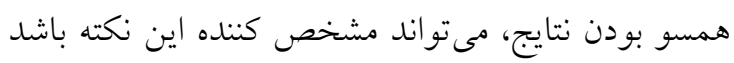

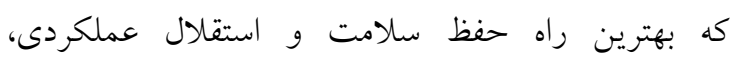

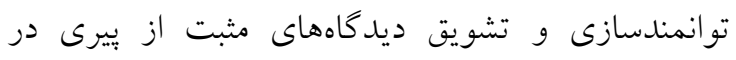

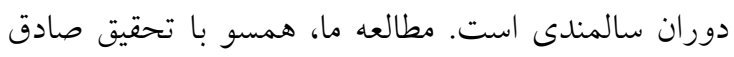

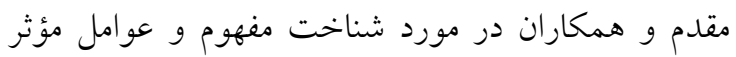
بر احساس بيّرى در سالمندان است كه به عنوان عامل

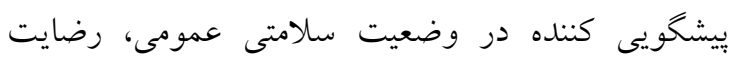

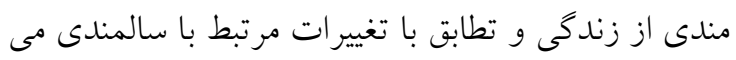

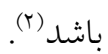
نتايج مطالعه كنونى در خصوص احساس ييرى و

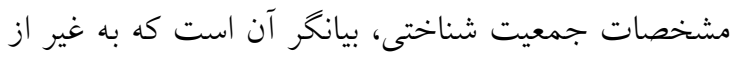
متغير سطح تحصيلات اختلاف معنىدارى از لحاظ آمارى

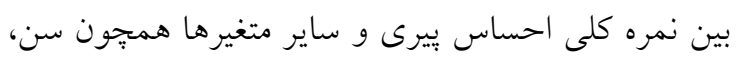
جنسيت و سلامت وجود داشته است. اين يافتهها با نتايج تحقيق Robertson و همكاران (IV) و همكاران(11) مطابقت دارد. در مطالعه Wurm و همكاران

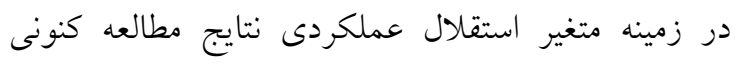

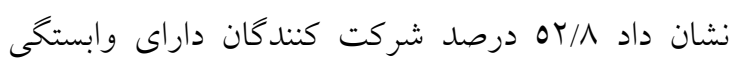

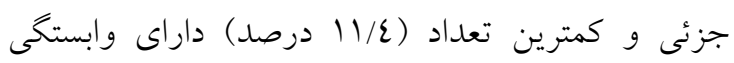
متوسط و يا مستقل در فعاليتهاى روزمره زندكى خود

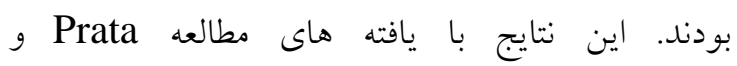

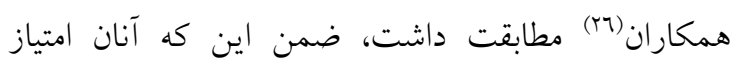
شاخص Barthel در سنجش استقلال عملكردى كه معادل فعاليت روزمره زندگى بود را در مردان سالمند نسبت به زنان سالمند بيشتر كزارش كرده بودند كه نشان رونان

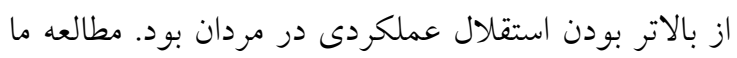

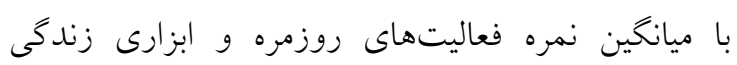

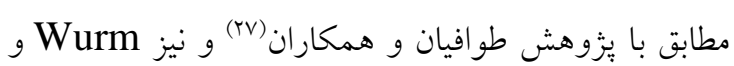
همكاران(10) بود كه بيانخر وابستخى كم و استقلال بيشتر

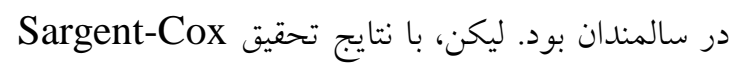

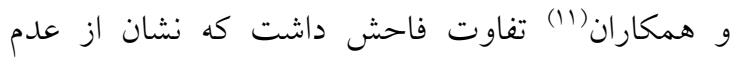

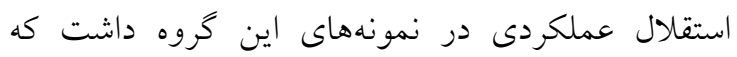
علت اين تفاوت شايد در سن سالمندان مورد مطالعه

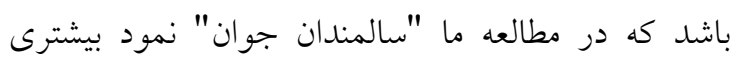

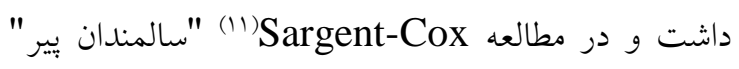

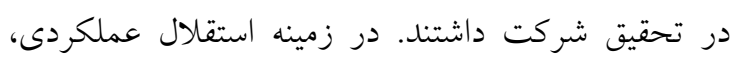

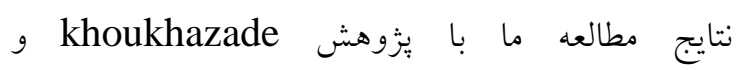

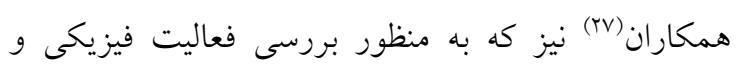
تعادل در •1/ سالمند مبتلا به ديابت در بيمارستان ايلام

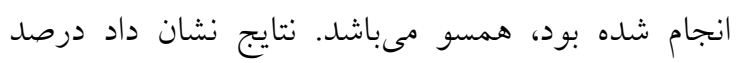

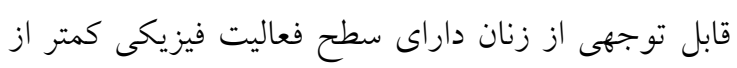
مردان بودند كه حاكى از تفاوت جنسيتى در اين مورد

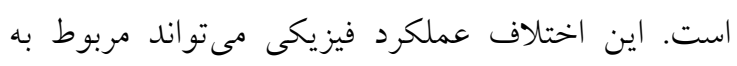

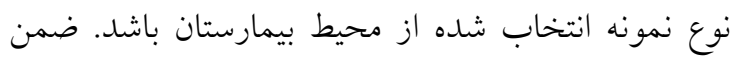
اين كه بيمارىهاى مزمن در حالت حاد مى توانند شديداً بر عملكرد فيزيكى سالمند تأثير كذار باشند.

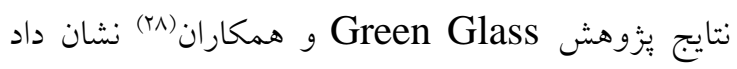

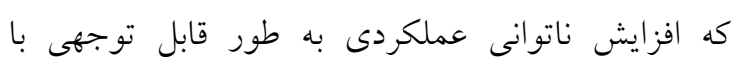
افزايش سن و سلامت جسمى ضعيف همراه است كه

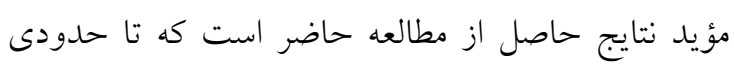


عمومى در بيماران قلبى (ro) و سرطان(T) تأكيد بر نقش (آش

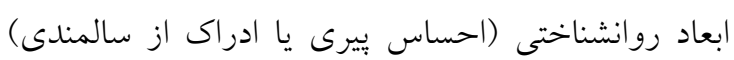
دارد، استقلال عملكردى سالمندان و دستيابى به مفهوم

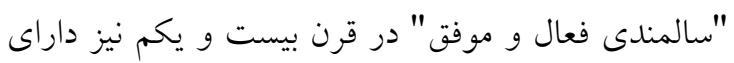

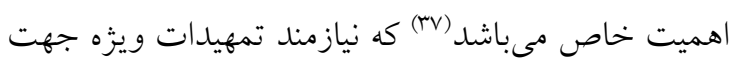
ارتقاء سلامت و برنامه ريزىهاى بهداشتى در اين قشر از جامعه است. ذكر اين نكته نيز ضرورى است كه در اين يزوهش، محدوديتهايى وجود داشت كه ير واضح است يافتههاى تحقيق نمىتواند تعميم يذيرى جֶندانى داشته باشد اما

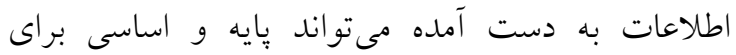

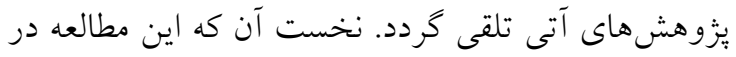
يكى از مراكز مشاورهاى ديابت در يكى از شهرستانهاى كوجّى (بروجن) انجام كرفته و نمونهها لزوماً نماينده كلى جامعه اير انى نيستند. بنابر اين بيشنهاد مى كردد جهرت

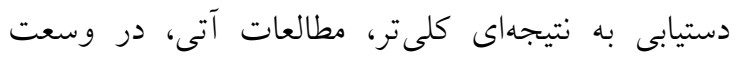
مكانى وسيعترى صورت كيرد. ضمن اين كه از ديخر

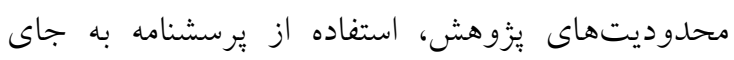
مصاحبه در اين تحقيق مقطعى (همبستكى توصيفى) بود. بنابراين ييشنهاد مىشود كه تحقيقات آتى در اين زمينه،

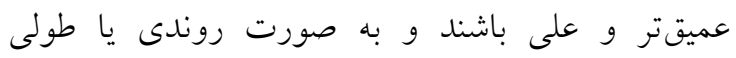

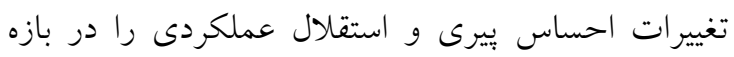
زمانى خاص مورد بررسى قرار دهند. در همين راستا

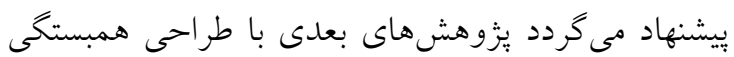

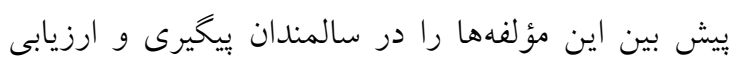
نمايند. با توجه به نتايج اين مطالعه كه ارتباط معنىدار و معكوسى را بين ادراك از سالمندى و استقلال عملكردى در كروه مورد مطالعه نشان داد، شناخت و آكاهى از اين كونه عوامل روانشناختى و ظرفيت عملكردى در قشر سالمندان مىتواند به سياست كذارى مرتبط با سلامت رت

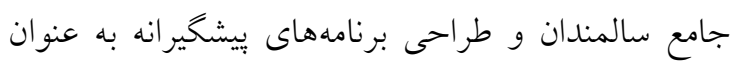

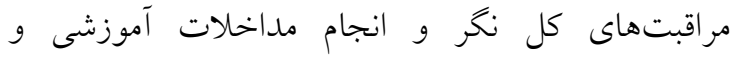

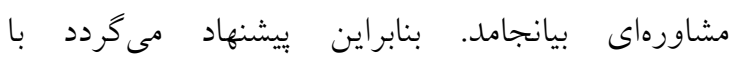

نيز مشخص مىشود كه ادراك از سالمندى با سن و

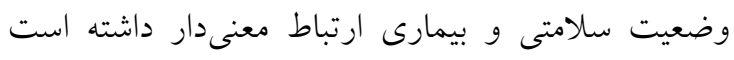

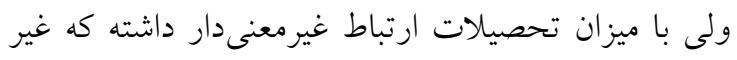

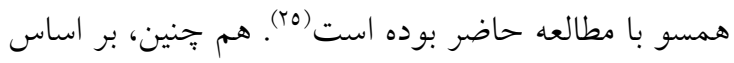
آزمونهاى آمارى تى مستقل و آناليز واريانس يكى طرفه به غير از متغيرهاى سطح تحصيلات و ساير بيمارىها اختلاف معنىدارى از لحاظ آمارى بين نمره كل استقلال عملكردى با ساير متغيرها هم:جون جنسيت، تأهل، سطح تحصيلات و وضعيت اقتصادى نيز وجود داشت. كر جها هنه در مطالعه حاضر استقلال عملكردى مردان نسبت به زنان سالمند بالاتر بود، يافتهها در مورد اطلاعات جمعيت شناختى به غير از سطح تحصيلات با نتايج مطالعات

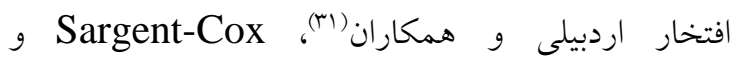

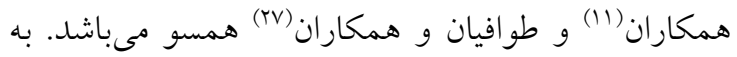
نظر مى آيد متغيرهاى جمعيت شناختى عواملى تأثير كذار بر وضعيت سلامتى و استقلال عملكردى سالمندان در

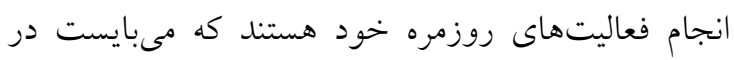

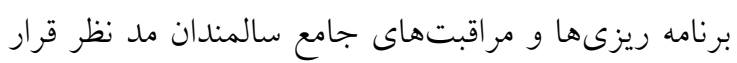

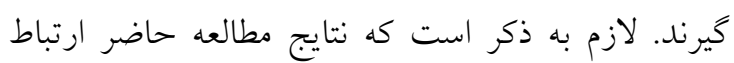

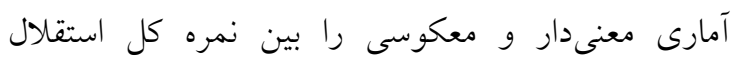
عملكردى و نمره كل احساس بيرى نشان داد كه يافته

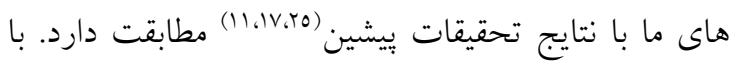

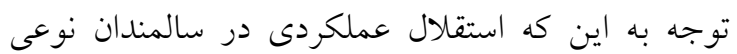

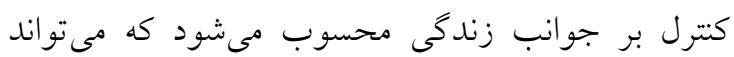
شاخصى تعيين كننده بر سلامتى انسانها تلقى شود (rr.r.r)

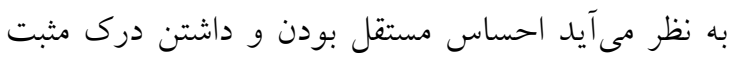

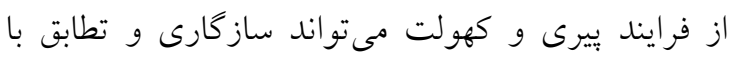
بيمارىهاى مزمن (از جمله ديابت) و بحرانها را افزايش داده و بر عكس، نداثتن استقلال و درك منفى از

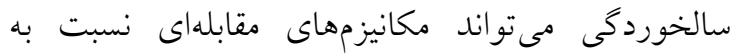

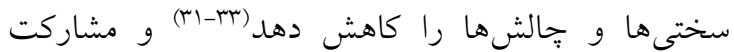
اجتماعى سالمند در جامعه را تحت الشعاع قرار دهد (عَم) كه به نحوى در كاهش سلامت اجتماعى مؤثر است. همجنان كه نتايج تحقيقات بيشين در حوزه سلامت 


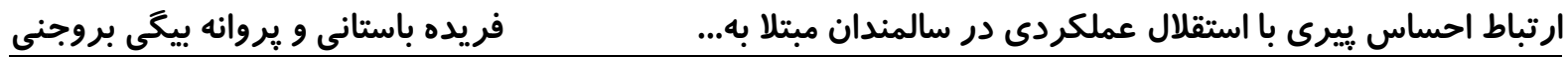

$$
\begin{aligned}
& \text { تقدير و تشكر }
\end{aligned}
$$

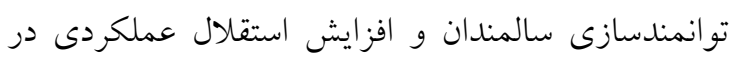

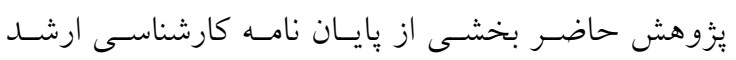

$$
\begin{aligned}
& \text { افراد سالخورده اثر مثبت بر ادراك اين خروه از سالمندان }
\end{aligned}
$$

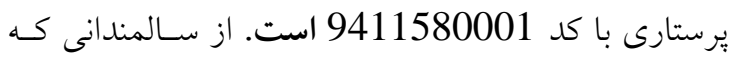

$$
\begin{aligned}
& \text { را بهبود بخشيد. }
\end{aligned}
$$

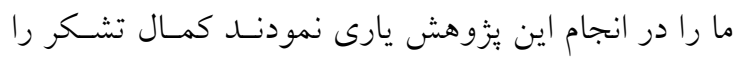

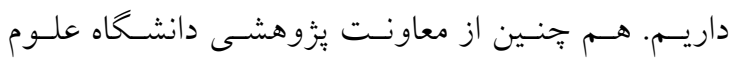

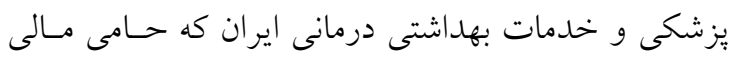

$$
\begin{aligned}
& \text { اين طرح بودند قدردانى مى گردد. }
\end{aligned}
$$

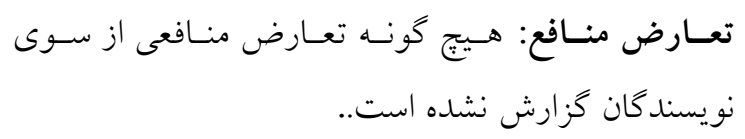

\section{References}

1. Ocampo JM. Self-rated health: Importance of use in elderly adults. Colombia Médica. 2010;41(3):275-89.

2. Sadegh Moghadam L, Foroughan M, Mohammadi F, Ahmadi F, Farhadi A, Nazari S, Sadeghi N. Aging perception in older adults. Iranian Journal of Ageing. 2016;10(4):202-9. [Persian]

3. Masoudnia E .Perception and Belifs on Aging and their impact on Elderly General Health. Iranian Journal of Ageing. 2016;11(2):310-20. [Persian]

4. Freitas MC, Queiroz TA, Sousa JA. The meaning of old age and the aging experience of in the elderly. Rev Esc Enferm USP. 2010;44(2):407-12.

5. da Rocha Fernandes J, Ogurtsova K, Linnenkamp U, Guariguata L, Seuring T, Zhang P, Cavan D, Makaroff LE. IDF Diabetes Atlas estimates of 2014 global health expenditures on diabetes. Diabetes Res Clin Pract. 2016;117:48-54.

6. Atlas IDF. International Diabetes Federation 2013. $6^{\text {th }}$ ed 2013.

7. Amiri M, Saghaei A, Abedi A. Effectiveness of stress inoculation training (SIT) on general health of diabetic patients. Journal Of Applied Psychology Winter 2011;4 (16): 85-100".[Persian]

8. Kent D, Haas L, Randal D, Lin E, Thorpe CT, Boren SA, Fisher J, Heins J, Lustman P, Nelson J, Ruggiero L. Healthy coping: issues and implications in diabetes education and care. Population health management. 2010;13(5):227-33.

9. Abazari P, Vanaki Z, Mohammadi E, Amini MM. Barriers to effective diabetes self-management education. Iranian Journal of Medical Education. 2013;13(3):221-32. [Persian]

10. I Ingrand I, Paccalin M, Liuu E, Gil R, Ingrand P. Positive perception of aging is a key predictor of quality-of-life in aging people. PloS one. 2018;13(10):e0204044.

11. Sargent-Cox KA, Anstey KJ, Luszcz MA. The relationship between change in self-perceptions of aging and physical functioning in older adults. Psychology and Aging. 2012;27(3):750.

12. Hsu HC, Tung HJ. Coping strategies and adaptation for the disabled elderly in Taiwan. Geriatr gerontol int. 2011;11(4):488-95.

13. Freeman AT, Santini ZI, Tyrovolas S, Rummel-Kluge C, Haro JM, Koyanagi A. Negative perceptions of ageing predict the onset and persistence of depression and anxiety: Findings from a prospective analysis of the Irish Longitudinal Study on Ageing (TILDA). J Affect Disord. 2016 15;199:132-8.

14. Lima-Costa MF, Firmo JO, Uchôa E. Differences in self-rated health among older adults according to socioeconomic circumstances: the Bambuí Health and Aging Study. Cadernos de Saúde Pública. 2005;21:830-9.

15. Moor C, Zimprich D, Schmitt M, Kliegel M. Personality, aging self-perceptions, and subjective health: A mediation model. Int J Aging Hum Dev. 2006;63(3):241-57.

16. Darvishpour KA, Abed SZ, Delavar A, Saeid AM. Autonomy in the elderly: a phenomenological study". Hakim Research Journal. 2010 ,12(4): 1 -10. [Persian]

17. Robertson DA, Kenny RA. Negative perceptions of aging modify the association between frailty and cognitive function in older adults. Personality and Individual Differences. 2016;100:120-5.

18. Ingrand I, Houeto JL, Gil R, Mc Gee H, Ingrand P, Paccalin M. The validation of a Frenchlanguage version of the Aging Perceptions Questionnaire (APQ) and its extension to a population aged 55 and over. BMC geriatrics. 2012;12(1):17. 
19. J Jung M, Muntaner C, Choi M. Factors related to perceived life satisfaction among the elderly in South Korea. J Prev Med Public Health. 2010;43(4):292-300.

20. Kim SH. Older people's expectations regarding ageing, health-promoting behaviour and health status. J Adv Nurs. 2009;65(1):84-91.

21. Bakhtiyari F, Foroughan M, Fakhrzadeh H, Nazari N, Najafi B, Alizadeh M, Arzaghi M, Sharifi F, Shoaee S, Mostafa Q. Validation of the persian version of Abbreviated Mental Test (AMT) in elderly residents of Kahrizak charity foundation. Iranian Journal of Diabetes and Metabolism. 2014;13(6):487-94. [Persian]

22. Tagharrobi Z, Sharifi K, Sooky Z. Psychometric evaluation of Shah version of modified Barthel index in elderly people residing in Kashan Golabchi nursing home. KAUMS Journal (FEYZ). 2011 Sep 15;15(3):213-24. [Persian]

23. Haghi Askarabadi F, Kraskepian A, Jamhari F. Determine the Psychometric Properties of Aging Perception Questionnaire (APQ). Journal of Psychometry. 2017; 6(22): 59-75. [Persian]

24. Borim FS, Neri AL, Francisco PM, Barros MB. Dimensions of self-rated health in older adults. Revista de saude publica. 2014;48:714-22.

25. Wurm S, Benyamini Y. Optimism buffers the detrimental effect of negative self-perceptions of ageing on physical and mental health. Psychology \& Health. 2014;29(7):832-48.

26. Prata MG, Scheicher ME. Correlation between balance and the level of functional independence among elderly people. Sao Paulo Med J. 2012;130(2):97-101.

27. Tavafian SS, Aghamolaei T, Moeini B. Functional independence level of physical activities in elderly people: a populationbased study. Journal of the Iranian Institute for Health Sciences Research / Payesh. 2014;(13) 4:449-56. [Persian]

28. Greenglass E, Fiksenbaum L, Eaton J. The relationship between coping, social support, functional disability and depression in the elderly. Anxiety, Stress, and Coping. 2006;19(1):15-31.

29. Robertson DA, Kenny RA. Negative perceptions of aging modify the association between frailty and cognitive function in older adults. Personality and Individual Differences. 2016;100:120-5.

30. Bastani F, Hosseiny RS, Baniasad M, Haghni H. Investigation of general health in female care givers of elderly people with alzheimer. Iranian Journal of Ageing. 2010;15;5(3):43-51. [Persian]

31. Eftekhar AH, Khatti DF, Batebi A, Shojaiezadeh D, Yazdani CJ. Frequency of functional and cognitive impairment and relevant factors in aging. Journal of Mazandaran University of Medical Sciences. 2012;22(96). [Persian]

32. Hamidi M, Zeeshan M, O'Keeffe T, Nisbet B, Northcutt A, Nikolich-Zugich J, Khan M, Kulvatunyou N, Fain M, Joseph B. Prospective evaluation of frailty and functional independence in older adult trauma patients. The American Journal of Surgery. 2018;216(6):1070-5.

33. Lachman ME, Neupert SD, Agrigoroaei S. The relevance of control beliefs for health and aging. In Handbook of the psychology of aging 2011 (pp. 175-90). Academic Press.

34. Robertson DA, Kenny RA. "I'm too old for that"-The association between negative perceptions of aging and disengagement in later life. Personality and Individual Differences. 2016;100:114-9.

35. Bastani FA, Hajizadeh SA, Saatchi KI, Haghani HA. Comparing the effect of acupressure and cryotherapy on the pain caused by removal of chest drain tube in the elderly patients undergoing open heart surgery'. Journal of Client-Centered Nursing Care. 2016 1;2(1):37-52. [Persian]

36. Nikzad S, Hashemi B, Hasan ZS, Mozdarani H, Baradaran-Ghahfarokhi M, Amini P. The application of the linear quadratic model to compensate the effects of prolonged fraction delivery time on a Balb/C breast adenocarcinoma tumor: An in vivo study. Int J Radiat Biol. 2016 $1 ; 92(2): 80-6$.

37. Abolhasani F, Bastani F. Successful Ageing in the Dimensions of Life Satisfaction and Perception of Ageing in the Iranian Elderly Adults Referring to the Health Center in the West of Tehran, Iran. Iran Journal of Nursing. 2019;31(116):61-74. [Persian] 